\title{
Electrochemical, Electrocatalytic, and Magnetic Properties of Vanadium-Containing Polyoxometalates
}

\author{
Joseph Dika Manga ${ }^{1,2}$, Anne-Lucie Teillout ${ }^{1}{ }^{(}$, Eric Rivière ${ }^{3}\left(\mathbb{C}\right.$, Pedro de Oliveira ${ }^{1}\left(\mathbb{C}\right.$ and Israël Martyr Mbomekallé ${ }^{1, *(\mathbb{C})}$ \\ 1 Institut de Chimie Physique, Campus d'Orsay, Université Paris-Saclay, UMR 8000 CNRS, Bâtiment 350, \\ 91405 Orsay, France; chendodemanga@gmail.com (J.D.M.); \\ anne-lucie.teillout@universite-paris-saclay.fr (A.-L.T.); \\ pedro.almeida-de-oliveira@universite-paris-saclay.fr (P.d.O.) \\ 2 Laboratoire de Chimie Analytique Structurale et des Matériaux, Département de Chimie, Faculté des Sciences \\ de l'Université de Douala, Douala BP 24157, Cameroon \\ 3 Institut de Chimie Moléculaire et des Matériaux d'Orsay, Campus d'Orsay, Université Paris-Saclay, \\ UMR 8182 CNRS, Bâtiment 420, 91405 Orsay, France; eric.riviere@universite-paris-saclay.fr \\ * Correspondence: israel.mbomekalle@universite-paris-saclay.fr
}

Citation: Manga, J.D.; Teillout, A.-L.; Rivière, E.; de Oliveira, P.;

Mbomekallé, I.M. Electrochemical, Electrocatalytic, and Magnetic Properties of Vanadium-Containing Polyoxometalates. Magnetochemistry 2021, 7, 157. https://doi.org/ 10.3390/magnetochemistry7120157

Academic Editor: Kevin Bernot

Received: 26 October 2021

Accepted: 30 November 2021

Published: 3 December 2021

Publisher's Note: MDPI stays neutral with regard to jurisdictional claims in published maps and institutional affiliations.

Copyright: (c) 2021 by the authors. Licensee MDPI, Basel, Switzerland. This article is an open access article distributed under the terms and conditions of the Creative Commons Attribution (CC BY) license (https:/ / creativecommons.org/licenses/by/ $4.0 /)$.

\begin{abstract}
Mono-substituted vanadium-containing Dawson-type polyoxometalates having the general formula $\alpha_{1}-\left[\mathrm{V}^{\mathrm{IV}} \mathrm{W}_{17} \mathrm{X}_{2} \mathrm{O}_{62}\right]^{8-}$ and $\alpha_{2}-\left[\mathrm{V}^{\mathrm{IV}} \mathrm{W}_{17} \mathrm{X}_{2} \mathrm{O}_{62}\right]^{8-}$, with $\mathrm{X}=$ As or $\mathrm{P}$, were synthesised and subject to a comprehensive electrochemical study comprising the $\mathrm{pH}$ dependency. These POMs exhibit an electrocatalytic behaviour towards the oxidation of thiols (namely cysteine), rendering them interesting species for mimicking oxidative stress situations, at physiological $\mathrm{pH}$ values. The efficiency of the electro-oxidation was assessed with thiols of different nature, and the substrate that responded best was used to compare the electrocatalytic capabilities of the POM series. The magnetic behaviour of these POMs was also evaluated and compared to their analogues, $\alpha_{1}$ - and $\alpha_{2}-\left[\mathrm{V}^{\mathrm{V}} \mathrm{W}_{17} \mathrm{X}_{2} \mathrm{O}_{62}\right]^{7-}(\mathrm{X}=\mathrm{As}$ or $\mathrm{P})$, at low temperatures and showed, as expected, a paramagnetic behaviour of $\mathrm{V}^{\mathrm{IV}}$ based compounds.
\end{abstract}

Keywords: polyoxometalates; vanadium; magnetism; electrochemistry; electroctalysis

\section{Introduction}

The polycondensation of oxoanions in aqueous or nonaqueous solution leads to the formation of large molecular structures referred to as polyoxometalates (POMs) [1,2]. A classic POM contains several oxygen atoms, and often hydrogen atoms and at least two other different elements in positive oxidation states. Its structure resembles a fit of discrete oxide fragments of defined sizes and shapes. Its formula is $\left[X_{x} M_{m} O_{y}\right]^{q-}$, where $M$ is generally tungsten, molybdenum, or vanadium, or other elements such as niobium, zinc, or tantalum. M can also be a mixture of these elements, which are then in their highest oxidation states. The element $X$, when it exists, is referred to as a hetero-element, and is usually an atom of phosphorus, arsenic, silicon, or any other transition or nonmetallic element [3].

POMs are characterised by the ratio $M / X$, which is the number of atoms of the condensed element, $\mathrm{M}$, to the number of atoms of the hetero-element, $\mathrm{X}$. Many compounds are obtained either by varying the $\mathrm{M} / \mathrm{X}$ ratio $(12,11,9,18,17 \ldots)$ or by changing $\mathrm{X}\left(\mathrm{Si}^{\mathrm{IV}}\right.$, $\left.\mathrm{Ge}^{\mathrm{IV}}, \mathrm{P}^{\mathrm{V}}, \mathrm{As}^{\mathrm{V}} \ldots\right)$ or $\mathrm{M}\left(\mathrm{W}^{\mathrm{VI}}, \mathrm{Mo}^{\mathrm{VI}}, \mathrm{V}^{\mathrm{V}} \ldots\right)$ [2]. Different models have been proposed to describe the arrangement of $\mathrm{M}$ atoms condensed around $\mathrm{X}$ hetero-atoms. These models all have in common the basic unit $\mathrm{MO}_{6}$, which is an octahedron whose apexes are each occupied by an oxygen atom, and the centre by the metal atom $\mathrm{M}$. In this study, we were interested in the $M / X=18 / 2$ model, known as the Dawson structure [4].

In the Dawson structure, the octahedra associate in two different ways: (1) three $\mathrm{MO}_{6}$ octahedra can join together at their vertices to form a trimetallic aggregate $\mathrm{M}_{3} \mathrm{O}_{13}$; (2) two 
$\mathrm{MO}_{6}$ octahedra will join together by sharing an edge to form a dimetallic unit $\mathrm{M}_{2} \mathrm{O}_{10}$. Using X-ray diffraction, Dawson showed that three $\mathrm{M}_{2} \mathrm{O}_{10}$ dimetallic units and one $\mathrm{M}_{3} \mathrm{O}_{13}$ trimetallic cluster join around a hetero-atom $\mathrm{X}$ to form the fragment $\left[\mathrm{XM}_{9} \mathrm{O}_{34}\right]^{\mathrm{m}-}$. The assembly of two such fragments leads to the structure $\alpha-\left[\mathrm{X}_{2} \mathrm{M}_{18} \mathrm{O}_{62}\right]^{\mathrm{n}-}$, as demonstrated by Lefort in 1882 [5], who indicated the value 9 for the $\mathrm{M} / \mathrm{X}$ ratio. The molecule thus has a $\sigma$ plane of symmetry separating its two identical halves, leading to the general formula $\left[\mathrm{X}_{2} \mathrm{M}_{18} \mathrm{O}_{62}\right]^{\mathrm{n}-}$. In 1947, Souchay showed that these compounds are in fact dimers and should be described as belonging to the $18 / 2$ model [6]. It was not until 1953 that Dawson used single-crystal X-ray diffraction to describe the structure of this molecule [4]. The structure shows that the metal atoms $M$ are divided into two groups: 6 atoms $(2 \times 3)$ in the apical position ("hat"), with the sites they occupy said to be of type $\alpha_{-2}$; and 12 atoms $(2 \times 6)$ in the equatorial position ("crown"), with the sites they occupy said to be of type $\alpha-1$ (Figure 1) [3,7].
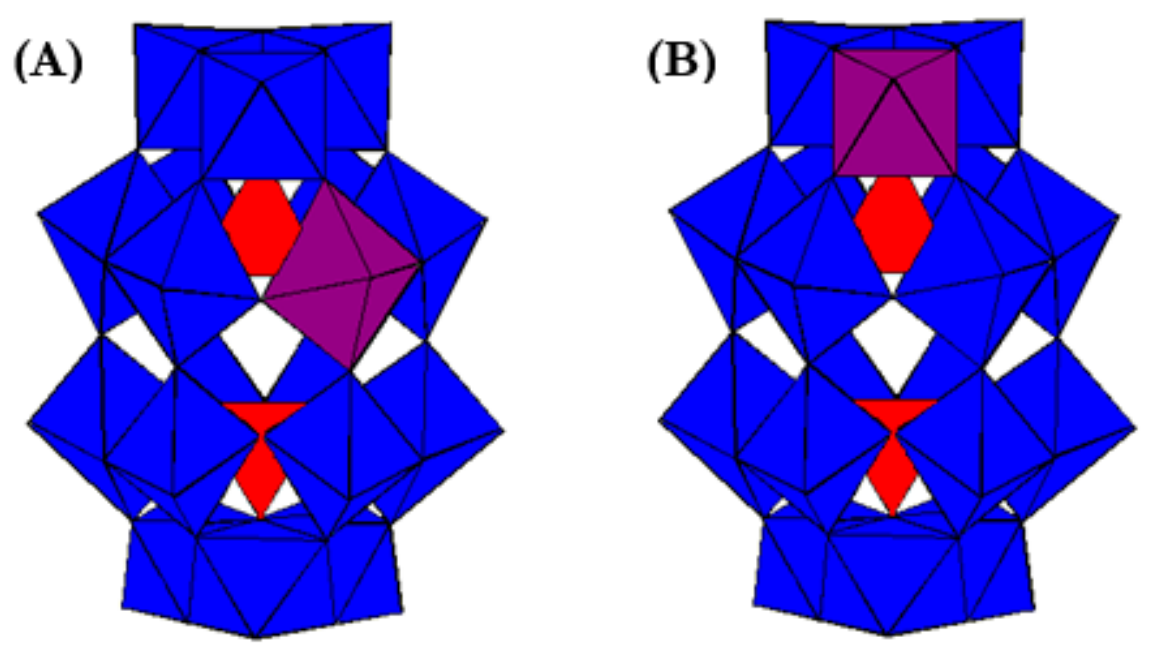

Figure 1. Polyhedral representations of the $\alpha_{-1}(\mathbf{A})$ and $\alpha_{-2}(\mathbf{B})$ isomers of the Dawson structure $\alpha-\left[\mathrm{X}_{2} \mathrm{M}_{18} \mathrm{O}_{62}\right]^{\mathrm{n}-}$.

In solution, the action of suitably chosen bases allows a Dawson-type POM to be partially and selectively hydrolysed, leading to the departure of one or more $\mathrm{MO}_{6}$ groups. This results in a Dawson-type structure with one or more vacant sites, some examples being $\alpha_{1}-\left[\mathrm{X}_{2} \mathrm{M}_{17} \mathrm{O}_{61}\right]^{\mathrm{n}-}, \alpha_{2}-\left[\mathrm{X}_{2} \mathrm{M}_{17} \mathrm{O}_{61}\right]^{\mathrm{n}-},\left[\mathrm{X}_{2} \mathrm{M}_{15} \mathrm{O}_{56}\right]^{\mathrm{n}-}$, and $\left[\mathrm{X}_{2} \mathrm{M}_{12} \mathrm{O}_{48}\right]^{\mathrm{n}-}$. From these lacunar compounds, mixed species can be prepared by inserting metal cations into the vacant sites. All these transformations allow the creation of a multitude of substituted POMs (for example: $\alpha_{1}$ - or $\alpha_{2}-\left[\mathrm{M}\left(\mathrm{H}_{2} \mathrm{O}\right) \mathrm{X}_{2} \mathrm{~W}_{17} \mathrm{O}_{61}\right]^{\mathrm{n}-}$ ) [8-10], mixed POMs (for example: $\alpha_{1}$ - or $\alpha_{2}-\left[\mathrm{X}_{2} \mathrm{Mo}_{\mathrm{x}} \mathrm{V}_{\mathrm{y}} \mathrm{W}_{18-(\mathrm{x}+\mathrm{y})} \mathrm{O}_{62}\right]^{\mathrm{n}-}$ ) [11-18], sandwich-type POMs [19-35] (for example: $\left.\left[\mathrm{M}_{4}\left(\mathrm{H}_{2} \mathrm{O}\right)_{2}\left(\mathrm{X}_{2} \mathrm{~W}_{15} \mathrm{O}_{56}\right)_{2}\right]^{16-}\right)$, or even more diverse structures [36-40].

In the unreduced state, the two compounds $\left[\mathrm{X}_{2} \mathrm{~W}_{18} \mathrm{O}_{62}\right]^{6-}$ (where $\mathrm{X}=\mathrm{As}$ or $\left.\mathrm{P}\right)$, which have all their tungsten atoms in the $+\mathrm{VI}$ oxidation state, are diamagnetic. It appears interesting to see how their electronic properties will evolve as a function of the nature, oxidation state, and position of substituents on the tungstic skeleton of these compounds.

In this study, we were interested in $\alpha_{1}-\mathrm{K}_{8}\left[\mathrm{X}_{2} \mathrm{~W}_{17} \mathrm{~V}^{4+} \mathrm{O}_{62}\right] 18 \mathrm{H}_{2} \mathrm{O}$ and $\alpha_{2}-\mathrm{K}_{8}\left[\mathrm{X}_{2} \mathrm{~W}_{17} \mathrm{~V}^{4+} \mathrm{O}_{62}\right]$ $18 \mathrm{H}_{2} \mathrm{O}$ substituted mixed compounds (with $\mathrm{X}=\mathrm{As}$ or $\mathrm{P}$ ) [41]. These compounds were synthesised from the two POMs $\alpha-\mathrm{K}_{6}\left[\mathrm{X}_{2} \mathrm{~W}_{18} \mathrm{O}_{62}\right] \cdot 14 \mathrm{H}_{2} \mathrm{O}$ (where $\mathrm{X}=\mathrm{As}$ or $\mathrm{P}$ ) [42,43], then characterised in solution by electrochemistry. The description of the syntheses of the different compounds used in this study is given in the ESI. Cyclic voltammetry allowed us to show the influence of $\mathrm{pH}$ on the redox properties of the four compounds. Magnetic studies carried out on the four compounds containing $\mathrm{V}^{4+}$ centres, as well as on the homologues containing $\mathrm{V}^{5+}$ centres, confirmed that the former were paramagnetic and the latter diamagnetic. 


\section{Materials and Methods}

All the compounds used in this study and their precursors were synthesised according to published methods, and their purity attested by electrochemistry [41-44]. Indeed, cyclic voltammetry and controlled potential coulometry are two electrochemical techniques that allow the unambiguous characterisation of POMs and the certification of their purity [45-47].

\subsection{Magnetic Properties}

Magnetic measurements were carried out with a MPMS-5 Quantum Design SQUID magnetometer with applied fields of $1 \mathrm{~T}$ for the $\mathrm{M}$ vs. T measurements and from 0 to $5 \mathrm{~T}$ for the $\mathrm{M}$ vs. H measurements at 6, 4, and $2 \mathrm{~K}$. Sample powders were pressed in pellets and held in a straw with sewing cotton to avoid sample holder corrections and the orientation of the crystallites along the magnetic field. The susceptibility data were corrected from diamagnetic contribution by using Pascal's tables.

\subsection{Electrochemistry}

Pure water was obtained with a Milli-Q Integral 5 purification set. All reagents were of high-purity grade and were used as purchased without further purification: $\mathrm{CH}_{3} \mathrm{CO}_{2} \mathrm{H}$ (Glacial, Fisher Scientific, Loughborough, UK), $\mathrm{H}_{2} \mathrm{SO}_{4}$ (Sigma Aldrich, Steinheim, Germany), $\mathrm{H}_{3} \mathrm{PO}_{4}$ (Prolabo, Briare le Canal, France), $\mathrm{Na}_{2} \mathrm{SO}_{4}$ (Sigma Aldrich, St. Louis, MO, USA, $\mathrm{NaCH}_{3} \mathrm{CO}_{2} 3 \mathrm{H}_{2} \mathrm{O}$ (Sigma Aldrich, St. Louis, MO, USA), $\mathrm{H}_{3} \mathrm{BO}_{3}$ (Sigma Aldrich, St. Louis, MO, USA), and $\mathrm{NaH}_{2} \mathrm{PO}_{4} \mathrm{H}_{2} \mathrm{O}$ (Merck, Darmstadt, Germany. The compositions of the various media were as follows: for $\mathrm{pH} 0.5,1.0,2.0$, and 3.0: $0.2 \mathrm{M} \mathrm{Na}_{2} \mathrm{SO}_{4}+\mathrm{H}_{2} \mathrm{SO}_{4}$; for $\mathrm{pH} 4.0$ and 5.0: $0.4 \mathrm{M} \mathrm{CH}_{3} \mathrm{COONa}+\mathrm{CH}_{3} \mathrm{COOH}$; for $\mathrm{pH} 6.0$ and 7.0: $0.4 \mathrm{M} \mathrm{NaH}_{2} \mathrm{PO}_{4}+\mathrm{NaOH}$; for experiments covering a $\mathrm{pH}$ range of1.0 to 8.0: Britton-Robinson buffer (see ESI, S3).

Electrochemical data were obtained using an EG \& G 273 A potentiostat driven by a PC with the M270 software. A divided cell with a standard three-electrode configuration was used for cyclic voltammetry experiments. The reference electrode was a saturated calomel electrode (SCE) and the counter electrode a platinum gauze of large surface area; both electrodes were separated from the bulk electrolyte solution via fritted compartments filled with the same electrolyte. The working electrode was a $3 \mathrm{~mm}$ outer diameter glassy carbon (GC) from Mersen, France. The pretreatment of the electrode before each experiment is adapted from a method described elsewhere [48]. Prior to each experiment, solutions were thoroughly deaerated for at least $30 \mathrm{~min}$ with pure argon. A positive pressure of this gas was maintained during subsequent work. The potentials are quoted against SCE unless otherwise stated, and all experiments were performed in solution at room temperature. Results were very reproducible from one experiment to the other, and slight variations observed over successive runs were rather attributed to the uncertainty associated with the detection limit of our equipment (potentiostat, hardware, and software) and not to the working electrode pretreatment, nor to possible fluctuations in temperature (polyanion concentrations: $0.5 \mathrm{mM}$ ).

\section{Results and Discussion}

\subsection{Cyclic Voltammetry Characterisation at $\mathrm{pH} 3$}

The four compounds, $\alpha_{1}-\mathrm{K}_{8}\left[\mathrm{As}_{2} \mathrm{~W}_{17} \mathrm{~V}^{4+} \mathrm{O}_{62}\right] \cdot 18 \mathrm{H}_{2} \mathrm{O}\left(\alpha_{1}-\mathrm{As}\right), \alpha_{2}-\mathrm{K}_{8}\left[\mathrm{As}_{2} \mathrm{~W}_{17} \mathrm{~V}^{4+} \mathrm{O}_{62}\right]$ $18 \mathrm{H}_{2} \mathrm{O}\left(\alpha_{2}-\mathrm{As}\right), \alpha_{1}-\mathrm{K}_{8}\left[\mathrm{P}_{2} \mathrm{~W}_{17} \mathrm{~V}^{4+} \mathrm{O}_{62}\right] 18 \mathrm{H}_{2} \mathrm{O}\left(\alpha_{1}-\mathrm{P}\right)$, and $\alpha_{2}-\mathrm{K}_{8}\left[\mathrm{P}_{2} \mathrm{~W}_{17} \mathrm{~V}^{4+} \mathrm{O}_{62}\right] 18 \mathrm{H}_{2} \mathrm{O}\left(\alpha_{2}-\mathrm{P}\right)$, were first characterised in the $0.2 \mathrm{M} \mathrm{Na}_{2} \mathrm{SO}_{4}+\mathrm{H}_{2} \mathrm{SO}_{4} / \mathrm{pH} 3$ medium, used as a reference $\mathrm{pH}$. These first results were in line with our expectations and the results of the scientific literature $[41,49,50]$. Indeed, in the cyclic voltammograms (CVs) in Figure 2a below and Figure S1a in the SI, we observed that the CVs of the phosphorus-containing species were slightly shifted to the left (towards the negative potentials) compared to the CVs of the arsenic-containing species. The $\mathrm{W}(\mathrm{VI})$ centres of the $\alpha_{1}$-As and $\alpha_{2}$-As species were more easily reduced than those of their phosphorus-containing counterparts $\left(\alpha_{1}-\mathrm{P}\right.$ and $\left.\alpha_{2}-\mathrm{P}\right)$. This difference in the reduction peak potential, $\Delta E_{c}$, between the different tungsten waves 
varied between 38 and $64 \mathrm{mV}$ for the $\alpha_{1}$-As and between 34 and $72 \mathrm{mV}$ for the $\alpha_{2}$-As (see Table 1). Indeed, previous studies have shown that Dawson-type POMs containing As as a hetero-element were easier to reduce than their P-containing counterparts [46,47]. This outcome, which has also been observed and studied in the case of Keggin-type POMs, was the consequence of differences in the atomic radius of the heteroatoms and in their electronegativities [51,52].
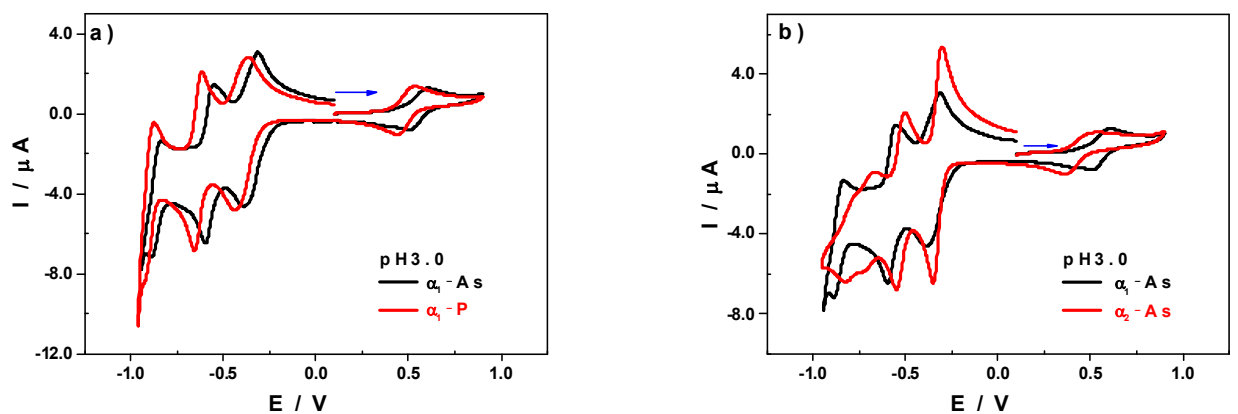

Figure 2. CVs of (a) $\alpha_{1}$-As (black) and $\alpha_{1}-\mathrm{P}$ (red); (b) $\alpha_{1}$-As (black) and $\alpha_{2}$-As (red) in $0.2 \mathrm{M} \mathrm{Na}_{2} \mathrm{SO}_{4}+\mathrm{H}_{2} \mathrm{SO}_{4} / \mathrm{pH}$. Working electrode: GC; counter electrode: Pt; reference electrode: SCE. Scan rate: $10 \mathrm{mV} \mathrm{s}^{-1}$.

Table 1. Oxidation peak potentials $\left(E_{a}\right)$ and reduction peak potentials $\left(E_{c}\right)$ measured from $C V$ secorded in $0.2 \mathrm{M} \mathrm{Na}_{2} \mathrm{SO}_{4}+$ $\mathrm{H}_{2} \mathrm{SO}_{4} / \mathrm{pH} 3$ (see above for the conditions).

\begin{tabular}{|c|c|c|c|c|c|c|}
\hline & $\mathrm{V}$ & $\mathrm{W}_{1}$ & $\mathrm{~W}_{2}$ & $\mathrm{~W}_{3}$ & $\mathrm{~W}_{4}$ & \multirow{5}{*}{$\alpha_{1}$-As } \\
\hline$E_{a}$ & 0.610 & -0.314 & -0.552 & -0.836 & - & \\
\hline$E_{c}$ & 0.514 & -0.386 & -0.596 & -0.884 & - & \\
\hline$E^{0^{\prime}}=\left(E_{a}+E_{c}\right) / 2$ & 0.562 & -0.350 & -0.574 & -0.860 & - & \\
\hline \multirow[t]{2}{*}{ \# electrons } & 1 & 2 & 2 & 2 & - & \\
\hline & $\mathrm{V}$ & $\mathrm{W}_{1}$ & $\mathrm{~W}_{2}$ & $\mathrm{~W}_{3}$ & $\mathrm{~W}_{4}$ & \multirow{5}{*}{$\alpha_{2}$-As } \\
\hline$E_{a}$ & 0.512 & -0.304 & -0.504 & -0.664 & -0.776 & \\
\hline$E_{c}$ & 0.366 & -0.350 & -0.550 & -0.728 & -0.826 & \\
\hline$E^{0^{\prime}}=\left(E_{a}+E_{c}\right) / 2$ & 0.439 & -0.327 & -0.527 & -0.696 & -0.801 & \\
\hline \multirow[t]{2}{*}{ \# electrons } & 1 & 2 & 2 & 1 & 1 & \\
\hline & $\mathrm{V}$ & $\mathrm{W}_{1}$ & $\mathrm{~W}_{2}$ & $\mathrm{~W}_{3}$ & $\mathrm{~W}_{4}$ & \multirow{5}{*}{$\alpha_{1}-\mathrm{P}$} \\
\hline$E_{a}$ & 0.532 & -0.366 & -0.616 & -0.874 & - & \\
\hline$E_{c}$ & 0.446 & -0.436 & -0.656 & -0.922 & - & \\
\hline$E^{0^{\prime}}=\left(E_{a}+E_{c}\right) / 2$ & 0.489 & -0.401 & -0.636 & -0.898 & - & \\
\hline \multirow[t]{2}{*}{ \# electrons } & 1 & 2 & 2 & 2 & - & \\
\hline & $\mathrm{V}$ & $\mathrm{W}_{1}$ & $\mathrm{~W}_{2}$ & $\mathrm{~W}_{3}$ & $\mathrm{~W}_{4}$ & \multirow{5}{*}{$\alpha_{2}-\mathrm{P}$} \\
\hline$E_{a}$ & 0.450 & -0.338 & -0.550 & -0.736 & -0.840 & \\
\hline$E_{c}$ & 0.346 & -0.386 & -0.586 & -0.774 & -0.876 & \\
\hline$E^{0^{\prime}}=\left(E_{a}+E_{c}\right) / 2$ & 0.398 & -0.362 & -0.568 & -0.755 & -0.858 & \\
\hline \# electrons & 1 & 2 & 2 & 1 & 1 & \\
\hline
\end{tabular}

On the other hand, and as a logical consequence, the $\mathrm{V}^{\mathrm{IV}}$ centre of the arseniccontaining species was more difficult to oxidise than that of the phosphorus-containing ones. For isomers $\alpha_{1}$, there was a potential difference of 78 in favour of $\alpha_{1}-\mathrm{P}$, and this difference was lower for isomers $\alpha_{2}$, with a value of $62 \mathrm{mV}$ in favour of $\alpha_{2}-\mathrm{P}$. 
The comparison of the CVs of the two isomers was also in line with the results of previous studies, and allowed us to distinguish them very clearly, especially at the level of their third reduction wave. Indeed, the third reduction step appeared as a two-electron wave with a single reduction peak located at $-0.882 \mathrm{~V}$ and $-0.922 \mathrm{~V}$ vs. SCE for $\alpha_{1}$-As and $\alpha_{1}-\mathrm{P}$, respectively; whereas in the case of the $\alpha_{2}$ isomers, this ultimate reduction occurred in two separate one-electron steps, each with reduction peaks located at $-0.728 \mathrm{~V}$ and $-0.826 \mathrm{~V}$ vs. SCE for $\alpha_{2}-\mathrm{As}$ and at $-0.774 \mathrm{~V}$ and $-0.876 \mathrm{~V}$ vs. SCE for $\alpha_{2}-\mathrm{P}$, respectively (Figure 2b and Figure S1b; Table 1).

\subsection{Influence of the $p H$}

It is known that, in general, in an aqueous medium, the exchange of electrons involving POMs on the interface between the solution and the surface of the working electrode is accompanied by an exchange of protons. It is therefore interesting to study the variation of the redox properties of these compounds as a function of the $\mathrm{pH}$, in a buffered medium. The four compounds were characterised in two other media, $0.4 \mathrm{M}$ $\mathrm{CH}_{3} \mathrm{CO}_{2} \mathrm{Na}+\mathrm{CH}_{3} \mathrm{CO}_{2} \mathrm{H} / \mathrm{pH} 5.0$ and $0.2 \mathrm{M} \mathrm{Na}_{2} \mathrm{HPO}_{4}+\mathrm{H}_{3} \mathrm{PO}_{4} / \mathrm{pH}$ 7.0.

When we went from $\mathrm{pH} 3.0$ to $\mathrm{pH} 5.0$ and then $\mathrm{pH} 7.0$, the redox potentials attributed to the tungstic centres became increasingly negative, whereas those of the vanadic centres remained invariant (Tables S1 and S2). It should be noted that in certain cases, this shifting of the redox waves towards more negative redox potentials was accompanied by a more or less marked evolution of their shapes (Figure 3). At pH 3.0, the first reduction step of the four compounds was bielectronic, and a well-defined wave with a single reduction peak was observed on the CVs. At pH 5.0, on the CVs of the $\alpha_{1}$ isomers, we observed a slight splitting of this wave with the appearance of a second distinct peak in the case of compound $\alpha_{1}-\mathrm{P}$, whereas in the case of compound $\alpha_{1}$-As, it was just a shoulder. At $\mathrm{pH} 7.0$, the separation was clear regardless of the CV of the compound considered. This observation showed that the capture of two electrons during the first reduction step was facilitated by the relatively high proton concentration of the $\mathrm{pH} 3.0$ medium. Indeed, the ratio of proton to $\mathrm{POM}$ concentration, $[\mathrm{H}+] /[\mathrm{POM}]$, was 2 at $\mathrm{pH} 3.0$. When we moved to pH 5.0 and pH 7.0, it was divided by 100 and by 10,000, respectively, which made electron transfer more difficult.
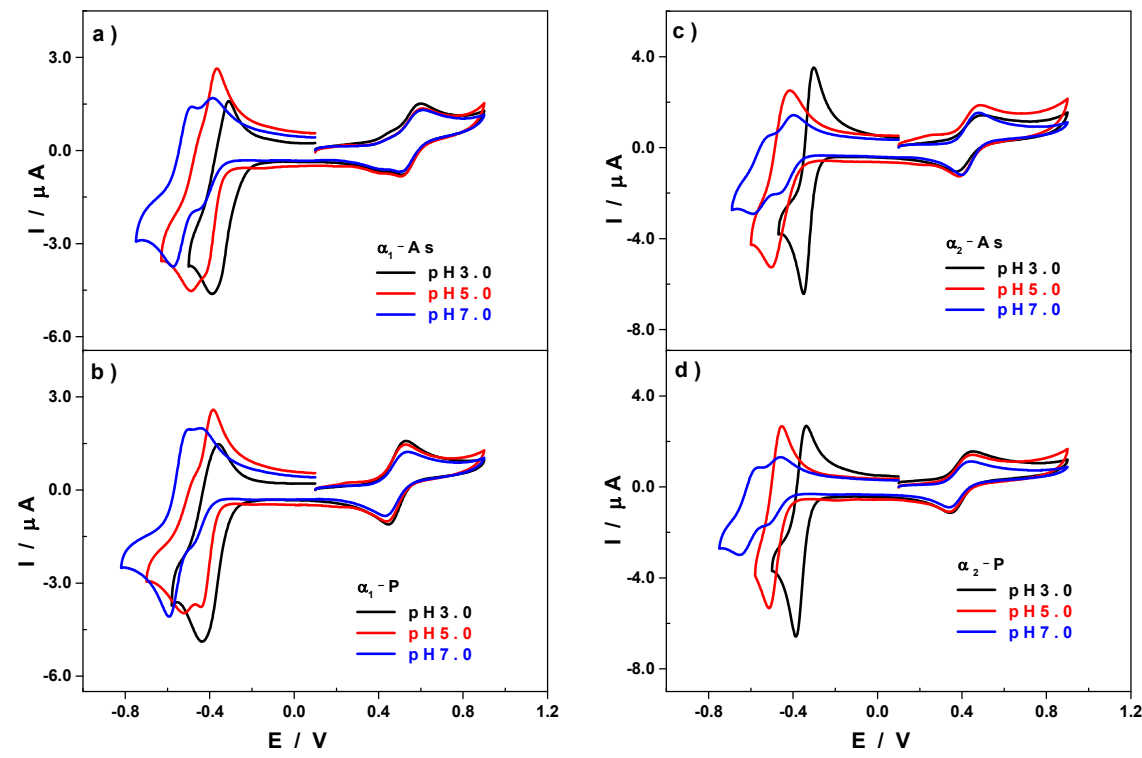

Figure 3. CVs of (a) $\alpha_{1}$-As; (b) $\alpha_{1}-\mathrm{P}$; (c) $\alpha_{2}$-As and (d) $\alpha_{2}-\mathrm{P}$ in $0.2 \mathrm{M} \mathrm{Na}_{2} \mathrm{SO}_{4}+\mathrm{H}_{2} \mathrm{SO}_{4} / \mathrm{pH} 3$ (black), $0.4 \mathrm{M} \mathrm{CH}_{3} \mathrm{CO}_{2} \mathrm{Na}+\mathrm{CH}_{3} \mathrm{CO}_{2} \mathrm{H} / \mathrm{pH} 5.0$ (red) and 0.2 $\mathrm{M} \mathrm{Na}_{2} \mathrm{HPO}_{4}+\mathrm{H}_{3} \mathrm{PO}_{4} / \mathrm{pH} 7.0$ (blue). Working electrode: GC; counter electrode: Pt; reference electrode: SCE. Scan rate: $10 \mathrm{mV} \mathrm{s}^{-1}$. 
A closer comparison of the CVs of the $\alpha_{1}$ isomers and those of the $\alpha_{2}$ isomers led us to make an observation that may have escaped us at first sight: as early as $\mathrm{pH} 3.0$, the first reduction step of $\alpha_{1}-\mathrm{X}(\mathrm{X}=\mathrm{As}$ or $\mathrm{P})$ was already more or less composite (Figure S2). Indeed, this first reduction wave presented a flattened cone shape compared to the pointed cone shape of the $\alpha_{2}$ isomer. The other observation worth noting was that only this first reduction step split into two monoelectronic steps when the $\mathrm{pH}$ of the medium increased. The other reduction steps were just shifted to negative potentials, without splitting. Moreover, the third reduction step of the $\alpha_{2}$ isomer merged with the fourth reduction step into a single, bielectronic step, as from pH 5.0 (Figure S3).

In order to be able to study all these phenomena, which seemed to be the consequence of the variation of the concentration of protons in the medium, and to eliminate any disturbance that would come from the nature of the electrolyte, we then chose to work with an electrolyte solution that had a buffering capacity in a wide $\mathrm{pH}$ window, the BrittonRobinson buffer (S3). For this study, only the phosphorus-based compounds, $\alpha_{1}-\mathrm{P}$ and $\alpha_{2}-\mathrm{P}$, were analysed in a $\mathrm{pH}$ range of 1.0 to 8.0 , a range in which these vanadic POMs have been shown to be stable [44]. A comparative study between the As- and the P-containing compounds did not appear to be of any interest, as the only difference observed between the two families of compounds was the potential shift mentioned above.

When looking at the redox behaviour of the vanadic centre, it can be seen that for both isomers $\alpha_{1}$ and $\alpha_{2}$, the value of the apparent potential, $E^{0^{\prime}}=\left(E_{a}+E_{c}\right) / 2$, of the $\mathrm{V}^{\mathrm{V} / \mathrm{IV}}$ couple remained invariant in this interval (Figure 4). We concluded that the oxidation of the $\mathrm{V}^{\mathrm{IV}}$ centre was not accompanied by an exchange of protons, but was just an exchange of electrons, as shown in the chemical equation (1) below:

$$
\mathrm{V}^{\mathrm{IV}}=\mathrm{V}^{\mathrm{V}}+\mathrm{e}^{-}
$$

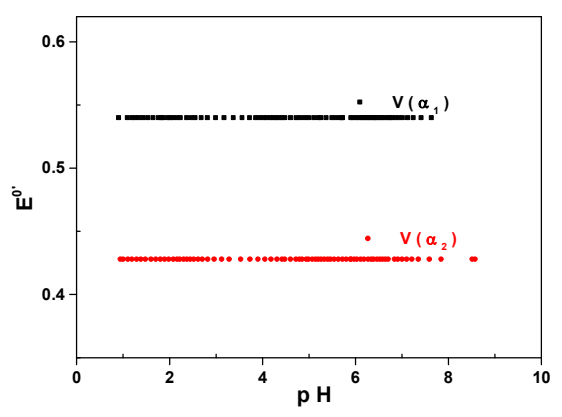

Figure 4. $E^{0^{\prime}}$ of $\mathrm{V}^{\mathrm{V} / \mathrm{IV}}$ as a function of the $\mathrm{pH}$ of the electrolyte (Britton-Robinson): $\alpha_{1}-\mathrm{P}$ (black squares); $\alpha_{2}-\mathrm{P}$ (red circles). Values were taken from $\mathrm{CVs}$ recorded as follows: working electrode: GC; counter electrode: $\mathrm{Pt}$; reference electrode: SCE. Scan rate: $100 \mathrm{mV} \mathrm{s}^{-1}$.

In the case of the redox processes attributed to the tungstic backbone, the redox behaviours of the two isomers were not similar, as was the case for the vanadic centre. In the case of the $\alpha_{1}$-P isomer, for example, one would have expected to see the first reduction wave lose its composite character completely when the $\mathrm{pH}$ of the electrolyte became well below 3. On the contrary, at $\mathrm{pH} 1.0$, the composite character of this first reduction wave was strengthened, and the CV recorded in this medium had a shoulder at $-0.22 \mathrm{~V}$ vs. SCE which stood out very clearly from the main peak located at $-0.32 \mathrm{~V}$ vs. SCE. The shape of the other two reduction waves that followed, although bielectronic, corresponded to a single reduction peak located at $-0.49 \mathrm{~V}$ and $-0.77 \mathrm{~V}$ vs. SCE, respectively (Figure 5a). Taking the $\mathrm{pH} 1.0$ solution as a starting point, and increasing the $\mathrm{pH}$ very slowly, we observed the progressive disappearance of the shoulder of the first wave. At $\mathrm{pH}$ 2.3, this shoulder had completely disappeared, and we had a slightly broad wave with a single reduction peak at $-0.39 \mathrm{~V}$ vs. SCE (Figure 5a). The CV of $\alpha_{1}-\mathrm{P}$ then consisted of three two-electron waves that shifted, all three towards negative potential values, as the $\mathrm{pH}$ of 
the solution increased. This pattern of three two-electron waves having a single reduction peak each would remain the same until $\mathrm{pH}$ values around 3.5.
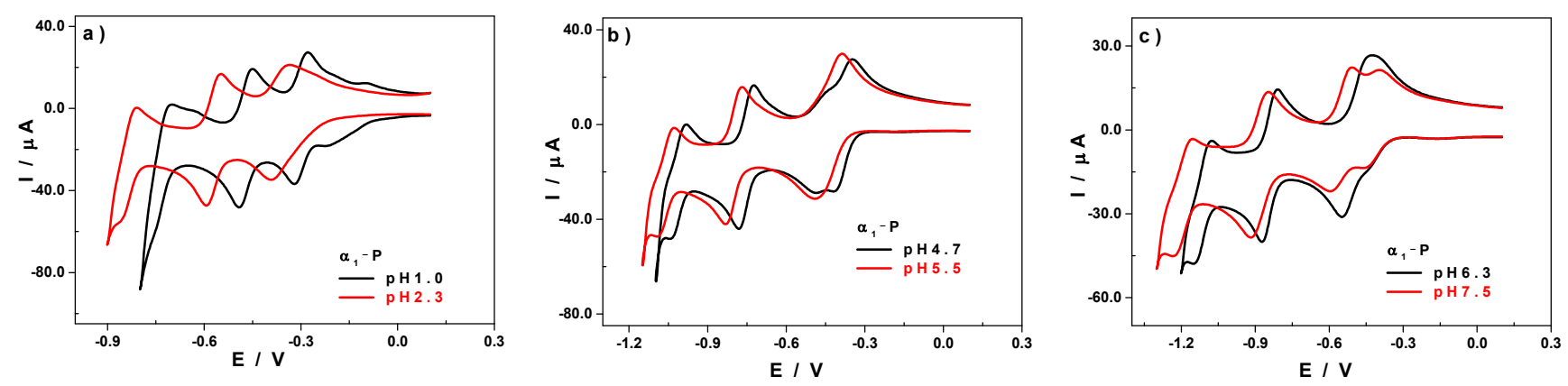

Figure 5. CVs of $\alpha_{1}-\mathrm{P}$ in Britton-Robinson buffer at several $\mathrm{pH}$ values: (a) $\mathrm{pH} 1.0$ (black) and pH 2.3 (red); (b) pH 4.7 (black) and pH 5.5 (red); (c) pH 6.3 (black) and pH 7.5 (red). Working electrode: GC; counter electrode: Pt; reference electrode: SCE. Scan rate: $100 \mathrm{mV} \mathrm{s}^{-1}$.

From $\mathrm{pH} 3.8$ onwards, the progressive separation of the first reduction wave into two more or less distinct steps was again observed. At $\mathrm{pH} 4.7$, there were two distinct reduction peaks at $-0.42 \mathrm{~V}$ and at $-0.49 \mathrm{~V}$ vs. SCE. These two peaks would gradually disappear to give way to a wave with a single reduction peak, as shown on the $\mathrm{CV}$ recorded at $\mathrm{pH} 5.5$ (Figure $5 b$ ). However, there would still be a final separation of this first reduction step, as from $\mathrm{pH} 6.3$.

Of the three reduction steps observable in this wide $\mathrm{pH}$ range, only the first wave exhibited this behaviour. As for the next two, the only observation made was the very expected decrease in the values of the reduction peak potentials when the $\mathrm{pH}$ of the electrolyte increased. However, it should be noted that, for the second reduction wave, a plateau was reached at $\mathrm{pH}$ values between 3.64 and 5.38. This behaviour already was noted in one of our previous studies, in which an inversion of the slope of the evolution of the reduction peak potential values was observed between $\mathrm{pH} 4$ and 5 [48].

The redox behaviour of the $\alpha_{2}-\mathrm{P}$ isomer as a function of the $\mathrm{pH}$ was more classical. No wave splitting was observed for $\mathrm{pH}$ values below 5.4 (Figure 6a). All three bielectronic waves shifted towards the negative potential values, with all three keeping their starting shapes almost unchanged. When we compared the first reduction of the $\alpha_{2}-\mathrm{P}$ isomer with that of the $\alpha_{1}$-P isomer, we realised that their behaviours, which seemed to diverge between $\mathrm{pH} 1.0$ and $\mathrm{pH} 5.4$, began to converge, as from $\mathrm{pH} 6.3$ (Figure S4). At pH 7.5, two almost superimposable monoelectronic waves were obtained (Figure 6b).
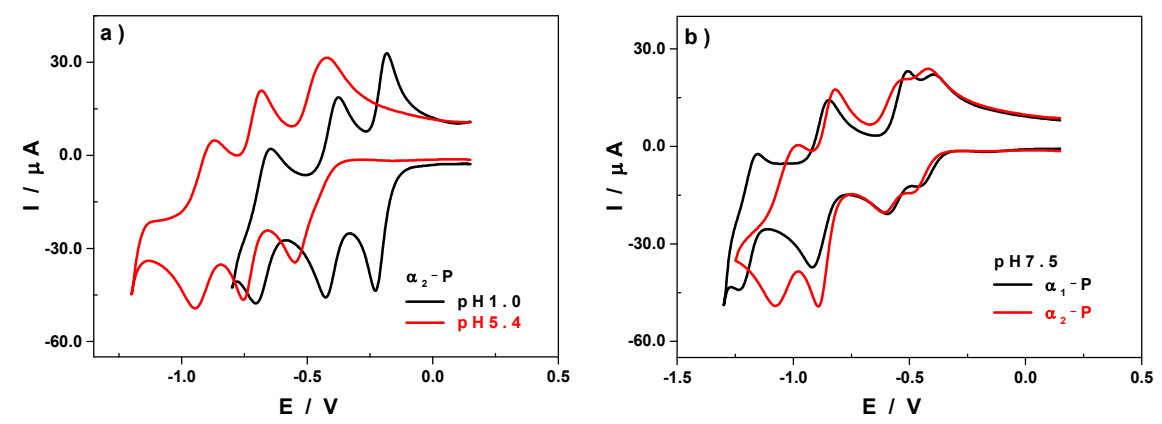

Figure 6. (a) CVs of $\alpha_{2}-\mathrm{P}$ in Britton-Robinson buffer at $\mathrm{pH} 1.0$ (black) and $\mathrm{pH} 5.4$ (red); (b) CVs of $\alpha_{1}-\mathrm{P}$ (black) and $\alpha_{2}-\mathrm{P}$ (red) in Britton-Robinson buffer at $\mathrm{pH}$ 7.5. Working electrode: GC; counter electrode: Pt; reference electrode: SCE. Scan rate: $100 \mathrm{mV} \mathrm{s}^{-1}$.

Let us now turn to the last reduction step of the $\alpha_{2}-\mathrm{P}$ isomer. Indeed, in the $\mathrm{pH}$ range between 2 and 4, this wave split to give two very distinct reduction peaks. Outside these two limits, as shown on the CVs in Figure S5, there was a single-peak reduction wave. This 
singular behaviour was only observed in the case of this isomer. Indeed, beyond the first reduction step, no wave splitting was observed in the case of the $\alpha_{2}$ isomer.

In summary, when the $\mathrm{pH}$ of the electrolyte was varied, the redox behaviour of the two isomers could be distinguished, as from the first reduction wave. The latter, which was globally bielectronic, could split into two monoelectronic steps or merge into a single step, depending on the $\mathrm{pH}$. The $\mathrm{pH}$ ranges in which the wave separation or fusion were observed were not identical for the two isomers (see Scheme 1). In fact, for the $\alpha_{2}$-isomer, the reduction took place in a single bielectronic step up to $\mathrm{pH}$ 5.5, and above this $\mathrm{pH}$ value, a process with two very distinct monoelectronic steps was observed. In the case of the $\alpha_{1}$-isomer, we observed an alternation of bielectronic and monoelectronic processes. Up to $\mathrm{pH} 1.9$, two single-electron steps were observed more or less distinctly, which merged from this $\mathrm{pH}$ value onwards into a single double-electron wave. A new separation was observed at $\mathrm{pH} 3.7$, from which two new monoelectronic steps would coexist until $\mathrm{pH}$, at which point they merged again. A final splitting took place, as from $\mathrm{pH}$ 6.2.

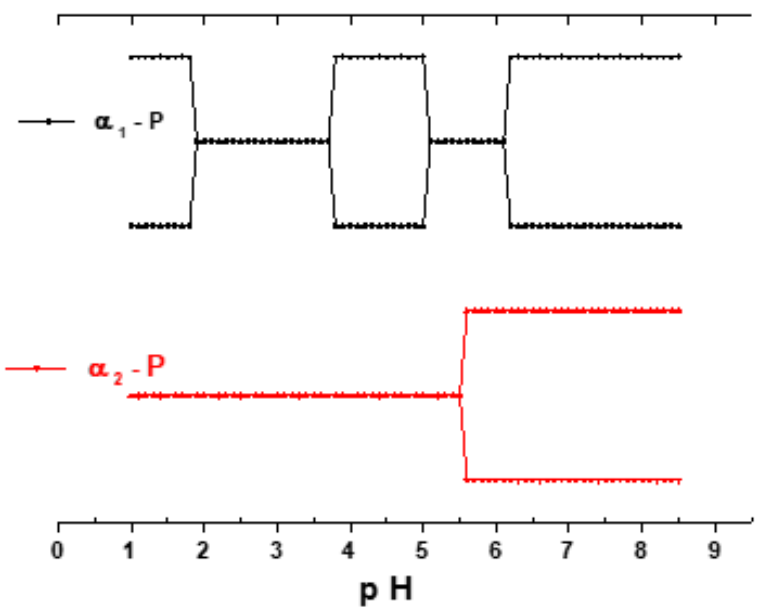

Scheme 1. Behaviour of the first reduction wave of the $\alpha_{1}-\mathrm{P}$ and the $\alpha_{2}-\mathrm{P}$ isomers as a function of the $\mathrm{pH}$ of the Britton-Robinson buffer solution.

The redox behaviour of the $\alpha_{1}-\mathrm{P}$ isomer was also singular at the second reduction wave (Figure $7 \mathrm{a}$ below). While the evolution of the reduction peak potentials as a function of the $\mathrm{pH}$ was continuous and uniform for the $\alpha_{2}$-P isomer (for $\mathrm{pH}<6.3$ ), a plateau was observed between $\mathrm{pH} 3.6$ and 4.6 for the $\alpha_{1}$-P isomer. On the other hand, the two isomers showed an almost identical behaviour as far as the third reduction wave was concerned. The evolution of the values of the reduction peak potentials as a function of the $\mathrm{pH}$ of the electrolyte followed a similar linear trend for both isomers (see SI). This corresponded broadly to the involvement of two protons concomitant with the exchange of two electrons.
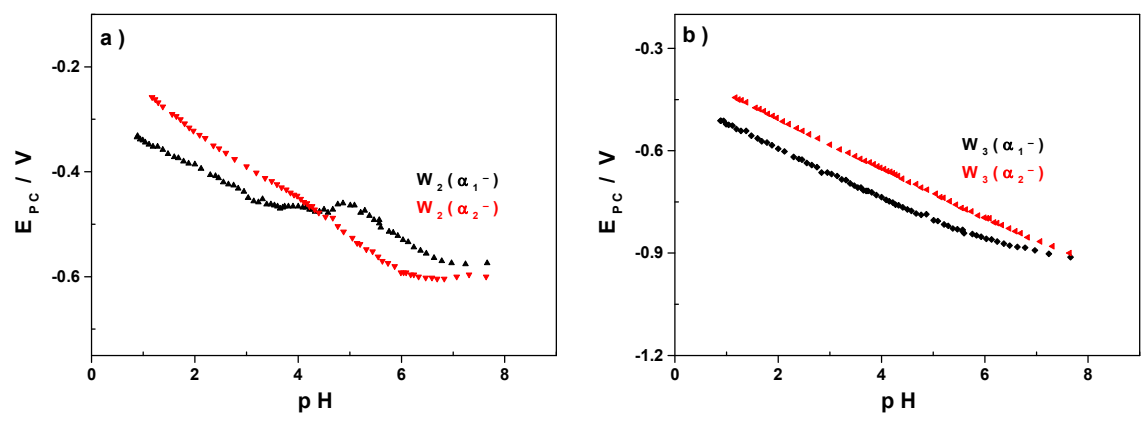

Figure 7. $E_{p c}$ of the tungstic centres as a function of the $\mathrm{pH}$ of the electrolyte (Britton-Robinson buffer) for $\alpha_{1}-\mathrm{P}$ (black) and $\alpha_{2}-\mathrm{P}$ (red): (a) second reduction wave; (b) third reduction wave. Values were taken from CVs recorded as follows: working electrode: GC; counter electrode: Pt; reference electrode: SCE. Scan rate: $100 \mathrm{mV} \mathrm{s}^{-1}$. 


\subsection{Electrocatalytic Properties}

The $0.2 \mathrm{M} \mathrm{Na}_{2} \mathrm{HPO}_{4}+\mathrm{H}_{3} \mathrm{PO}_{4} / \mathrm{pH} 7.0$ medium was selected to evaluate and compare the efficiency of the four compounds with respect to the electro-oxidation of a thiol (3mercaptopropanol). For this purpose, we will focus on the $\mathrm{V}^{\mathrm{V} / \mathrm{IV}}$ redox couple. We observed for each of the compounds a reversible and monoelectronic oxidation wave when they were the sole electroactive species in solution, as shown in Figures S6b and S7a. In the presence of the thiol, we noticed the exponential increase of the oxidation current, as well as the loss of reversibility of the said waves. These two phenomena clearly indicated the existence of an electrocatalytic process at the level of the $\mathrm{V}^{\mathrm{V} / \mathrm{IV}}$ wave (Figure 8a, Figures S6a and S7b). Two parameters allowed us to quantify and compare the efficiency of these four compounds with respect to the electrocatalytic oxidation of the thiol: (1) the catalytic efficiency, CAT, which was calculated using the formula $C A T=\left[\left(I_{c a t}-I_{0}\right) / I_{0}\right] \times 100$; and (2) the onset potential of the catalytic reaction, ONSET.
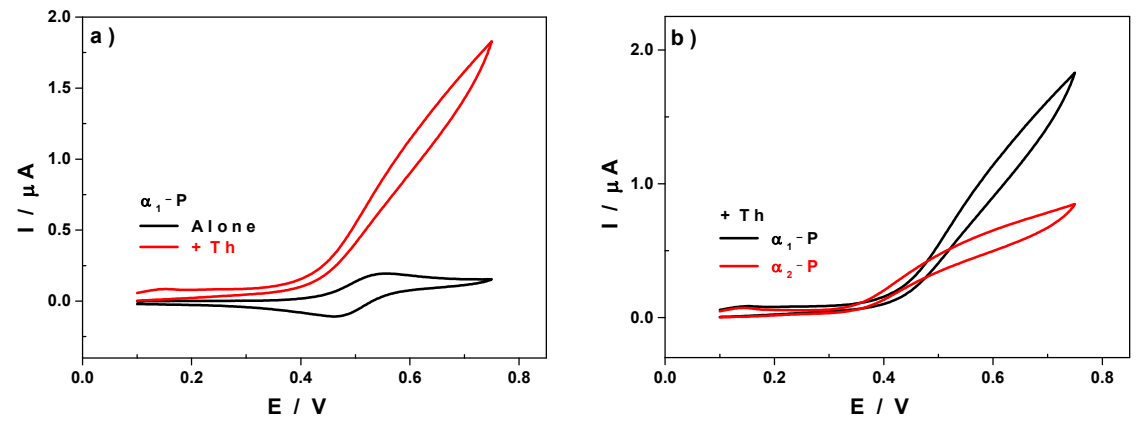

Figure 8. (a) CVs of $\alpha_{1}-\mathrm{P}$ alone (black) and in presence of the thiol (red); (b) CVs in presence of the thiol for $\alpha_{1}-\mathrm{P}$ (black) and $\alpha_{2}-\mathrm{P}$ (red). Electrolyte, $0.2 \mathrm{M} \mathrm{Na}_{2} \mathrm{HPO}_{4}+\mathrm{H}_{3} \mathrm{PO}_{4} / \mathrm{pH}$ 7.0. Working electrode: GC; counter electrode: Pt; reference electrode: SCE. Scan rate: $2 \mathrm{mV} \mathrm{s}^{-1}$. Concentrations: $[\mathrm{POM}]=0.2 \mathrm{mM}$, [Thiol $]=5.0 \mathrm{mM}$.

As expected, the electrocatalytic process began earlier in the case of the $\alpha_{2}$-isomers, for which the oxidation of the vanadium centre took place at more favourable potentials. However, when comparing the CAT values calculated at the same potential $(\mathrm{E}=0.75 \mathrm{~V}$ vs. SCE), it became clear that the $\alpha_{1}$-isomers showed the highest catalytic efficiency (Table 2). This was in agreement with previous experimental and theoretical studies, which showed that the electron density was higher at the equatorial region of the Dawson structure (position $\alpha_{1^{-}}$) than at its apical region (position $\alpha_{2}$ ) [53,54].

Table 2. Oxidation peak currents in the absence $\left(I_{0}\right)$ and in the presence $\left(I_{C A T}\right)$ of thiol. $C A T$ and ONSET data were calculated or measured from values taken from CVs recorded in $0.2 \mathrm{M}$ $\mathrm{Na}_{2} \mathrm{HPO}_{4}+\mathrm{H}_{3} \mathrm{PO}_{4} / \mathrm{pH} 7.0$ (see above for the conditions).

\begin{tabular}{lcccc}
\hline & $\boldsymbol{\alpha}_{\mathbf{1}}$-As & $\boldsymbol{\alpha}_{\mathbf{2}}$-As & $\boldsymbol{\alpha}_{\mathbf{1}}$-P & $\boldsymbol{\alpha}_{\mathbf{2}}$-P \\
\hline$I_{0}(\mu A)$ & 0.17 & 0.16 & 0.15 & 0.15 \\
\hline$I_{\text {cat }}(\mu A)$ & 1.86 & 1.34 & 1.83 & 0.85 \\
\hline CAT $(\%)$ & 994 & 738 & 1120 & 467 \\
\hline ONSET $(V$ vs. SCE) & 0.42 & 0.35 & 0.42 & 0.37 \\
\hline
\end{tabular}

\section{Magnetic Properties}

The magnetic behaviours of the four $\mathrm{V}^{4+}$ compounds $\left(\alpha_{1}-\mathrm{As}^{4+}, \alpha_{2}-\mathrm{As}^{4+}, \alpha_{1}-\mathrm{P} \mathrm{V}^{4+}\right.$, and $\left.\alpha_{2}-\mathrm{PV}^{4+}\right)$ and two $\mathrm{V}^{5+}$ compounds $\left(\alpha_{2}-\mathrm{AsV}^{5+}\right.$ and $\left.\alpha_{2}-\mathrm{PV}^{5+}\right)$ were investigated.

$\mathrm{V}^{5+}$ compounds were assumed to be diamagnetic, but their characterisation could allow us to evaluate the diamagnetic correction that should be applied for the calculation of the magnetization of $\mathrm{V}^{4+}$ compounds. Indeed, this evaluation by Pascal's tables is 
always delicate in the case of POMs, as is the case for $\mathrm{V}^{4+}$ POMs, for which we had only a spin $1 / 2$ for a molar mass of the order of 4900 g.mol ${ }^{-1}$ and an important number of water molecules.

$\mathrm{M}$ vs. $\mathrm{B}$ at $2 \mathrm{~K}$ plots are shown in Figure 9, and $\chi_{m} T$ vs. $T$ curves (where $\chi_{m}$ is the molar susceptibility) in the range of 250 to $2 \mathrm{~K}(\mathrm{~B}=1 \mathrm{~T})$ in Figure 10. Both compounds presented a weak paramagnetic behaviour that may have been due to $\mathrm{V}^{4+}$ impurities. The amount of impurities could be deduced from the $\mathrm{M}$ vs. $\mathrm{B}$ curves at $2 \mathrm{~K}$. For an ion $\mathrm{S}=1 / 2$ with $\mathrm{g}=2$, the value of the magnetization expected at $5 \mathrm{~T}$ was $0.93 \mu \mathrm{B}$ (black curve in Figure 9). Here, for $\alpha_{2}-\mathrm{AsV}^{5+}$ the magnetization was $0.0115 \mu \mathrm{B}$ and 0.0313 for $\alpha_{2}-\mathrm{PV}^{5+}$, representing about $1.2 \%$ and $3.3 \%$ of impurities, respectively.

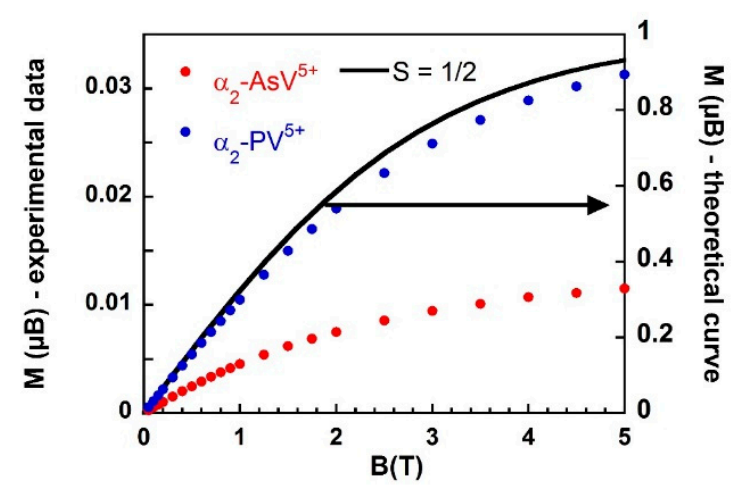

Figure 9. $\mathrm{M}$ vs. B measurements for $\alpha_{2}-\mathrm{AsV}^{5+}(\bullet)$ and $\alpha_{2}-\mathrm{PV}^{5+}(\bullet)$ at $2 \mathrm{~K}$ compared to the theoretical curve for $S=1 / 2$.

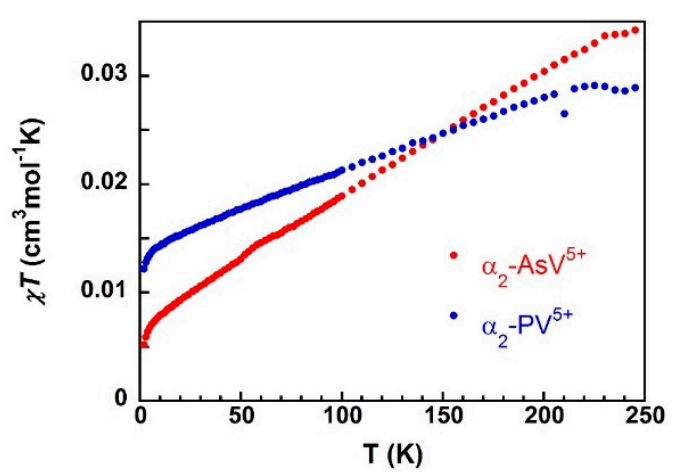

Figure 10. $\chi T$ vs. $T$ curves for $\alpha_{2}-\mathrm{AsV}^{5+}(\bullet)$ and $\alpha_{2}-\mathrm{PV}^{5+}(\bullet)$ under a magnetic field of $1 \mathrm{~T}$.

For $\alpha_{2}-\mathrm{AsV}^{5+}$ and $\alpha_{2}-\mathrm{PV}^{5+}$, the $\chi_{m} T$ decreased linearly from $0.035 \mathrm{~cm}^{3} \cdot \mathrm{mol}^{-1} \mathrm{~K}$ $\left(0.03 \mathrm{~cm}^{3} \cdot \mathrm{mol}^{-1} \cdot \mathrm{K}\right.$, respectively) at $250 \mathrm{~K}$ to about $0.009 \mathrm{~cm}^{3} \mathrm{~mol}^{-1} \mathrm{~K}(0.015)$ at $20 \mathrm{~K}$. If it is expected that the impurity obeys Curie's law, the slope of this straight line can be due to the presence of temperature-independent paramagnetism (TIP) relative to the POM. Curie's law can be written: $\chi_{M} T=\mathrm{x}_{\mathrm{i}} \mathrm{C}+\chi_{T I P} . T$, where $\mathrm{C}$ stands for the Curie constant, $\mathrm{x}_{\mathrm{i}}$ the fraction of impurity, and $\chi_{T I P}$ the TIP. The value obtained for the TIP was $115 \times 10^{-6} \mathrm{~cm}^{3} \cdot \mathrm{mol}^{-1}$ for $\alpha_{2}-\mathrm{AsV}^{5+}$ and $16 \times 10^{-6} \mathrm{~cm}^{3} \mathrm{~mol}^{-1}$ for $\alpha_{2}-\mathrm{PV}^{5+}$. TIP with similar values could be expected for the $\mathrm{V}^{4+}$ compounds.

Regarding to the $\mathrm{V}^{4+}$ compounds, the results are shown in Figure 11 in the form of $\chi_{m} T$ vs. $T$ plots. 


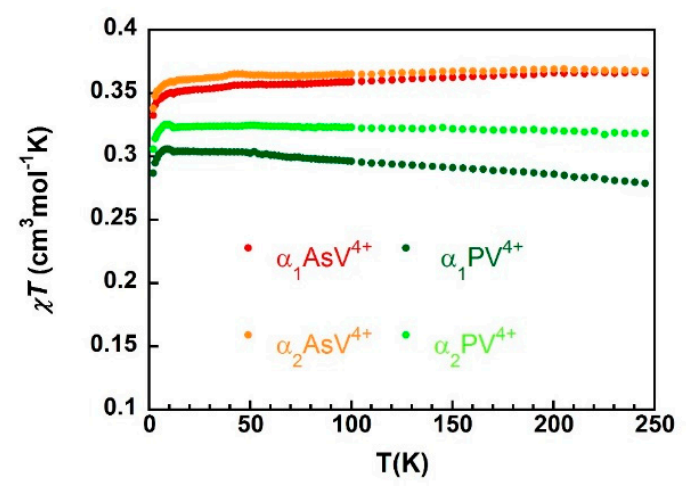

Figure 11. Susceptibility measurements under an applied field of $1 \mathrm{~T}$ in the form of $\chi_{m} T$ vs. $T$ plots for $\alpha_{1}-\mathrm{AsV}^{4+}(\bullet), \alpha_{2}-\mathrm{As} \mathrm{V}^{4+}(\bullet), \alpha_{1}-\mathrm{PV}^{4+}(\bullet)$ and $\alpha_{2}-\mathrm{PV}^{4+}(\bullet)$.

At $250 \mathrm{~K}$, the $\chi_{m} T$ values for $\alpha_{1}-\mathrm{AsV}^{4+}$ and for $\alpha_{2}-\mathrm{AsV}^{4+}$ were 0.366 and $0.368 \mathrm{~cm}^{3} . \mathrm{mol}^{-1} . \mathrm{K}$, respectively, and close to $0.375 \mathrm{~cm}^{3} \cdot \mathrm{mol}^{-1} \cdot \mathrm{K}$, as expected for a $\mathrm{S}=1 / 2$ ion with $\mathrm{g}=2$. However, for $\alpha_{1}-\mathrm{PV}^{4+}$ and $\alpha_{2}-\mathrm{PV}^{4+}$, the values were weaker than expected $(0.278$ and $0.317 \mathrm{~cm}^{3} \cdot \mathrm{mol}^{-1} \mathrm{~K}$, respectively).

For the As compounds, $\chi_{m} T$ decreased linearly when lowering the temperature from $250 \mathrm{~K}$ to $20 \mathrm{~K}$. As seen previously, this may have been due to presence of TIP, which could be estimated at $60 \times 10^{-6}$ and $29 \times 10^{-6} \mathrm{~cm}^{3} \cdot \mathrm{mol}^{-1}$ for $\alpha_{1}-\mathrm{AsV}^{4+}$ and $\alpha_{2}-\mathrm{AsV}^{4+}$, respectively. The Curie constants and the corrections deducted from these measurements are summarised in Table 3 . Below $20 \mathrm{~K}$, the decrease of $\chi T$ was faster to reach 0.332 and $0.338 \mathrm{~cm}^{3} \cdot \mathrm{mol}^{-1} \mathrm{~K}$. This decrease was expected at low temperatures under a magnetic field of $1 \mathrm{~T}$ (see Figure S8).

Table 3. Curie constants and corrections of the susceptibilities deducted from the $\chi \mathrm{T}$ vs. T measurements and g values calculated from the Brillouin function for the $\mathrm{AsV}^{4+}$ and the $\mathrm{PV}^{4+}$ compounds.

\begin{tabular}{|c|c|c|c|c|c|c|}
\hline & & $S=1 / 2$ (S.O.) & $\alpha_{1}-\mathrm{AsV}^{4+}$ & $\alpha_{2}-\mathrm{AsV}^{4+}$ & $\alpha_{1}-\mathrm{PV}^{4+}$ & $\alpha_{2}-\mathrm{PV}^{4+}$ \\
\hline \multirow{3}{*}{$\chi T$ vs. $T$} & $C\left(\mathrm{~cm}^{3} \cdot \mathrm{mol}^{-1}\right)$ & 0.375 & 0.352 & 0.362 & 0.307 & 0.325 \\
\hline & $\chi_{\mathrm{TIP}}\left(\mathrm{cm}^{3} \cdot \mathrm{mol}^{-1}\right)$ & & $60 \times 10^{-6}$ & $29 \times 10^{-6}$ & & \\
\hline & $\chi_{\text {dia }}\left(\mathrm{cm}^{3} \cdot \mathrm{mol}^{-1}\right)$ & & & & $-112 \times 10^{-6}$ & $-25 \times 10^{-6}$ \\
\hline$M$ vs. $B$ & $g$ & 2.0 & 1.91 & 1.93 & 1.75 & 1.82 \\
\hline
\end{tabular}

For the P compounds, the $\chi_{m} T$ increased linearly when lowering the temperature. This may have indicated that the diamagnetism was not correctly taken into account. An additional correction $\left(\chi_{\text {dia }}\right)$ of $-112 \times 10^{-6}$ and $-25 \times 10^{-6} \mathrm{~cm}^{3} \cdot \mathrm{mol}^{-1}$ for $\alpha_{1}-\mathrm{PV}^{4+}$ and $\alpha_{2}-\mathrm{PV}^{4+}$, respectively, was added so that Curie's law was verified $\left(\chi_{m} T=C+\chi_{\text {dia }} T\right)$.

Nevertheless, to exclude other possibilities of such behaviour (antiferromagnetic coupling for the As-containing POMs or ferromagnetic coupling for the P-containing POMs), magnetization $M$ vs. field $B$ measurements were carried out at low temperatures $(6,4$, and $2 \mathrm{~K})$. The results are depicted in Figure 12. These curves, in the form of M vs. B/T plots, could be simulated with a Brillouin function [55] for a $S=1 / 2$ ion, thus showing that the $\mathrm{V}^{4+}$ ions were isolated, and that the decrease or the increase observed in $\chi_{m} T$ in the range $20-250 \mathrm{~K}$ was not the result of a magnetic coupling. 

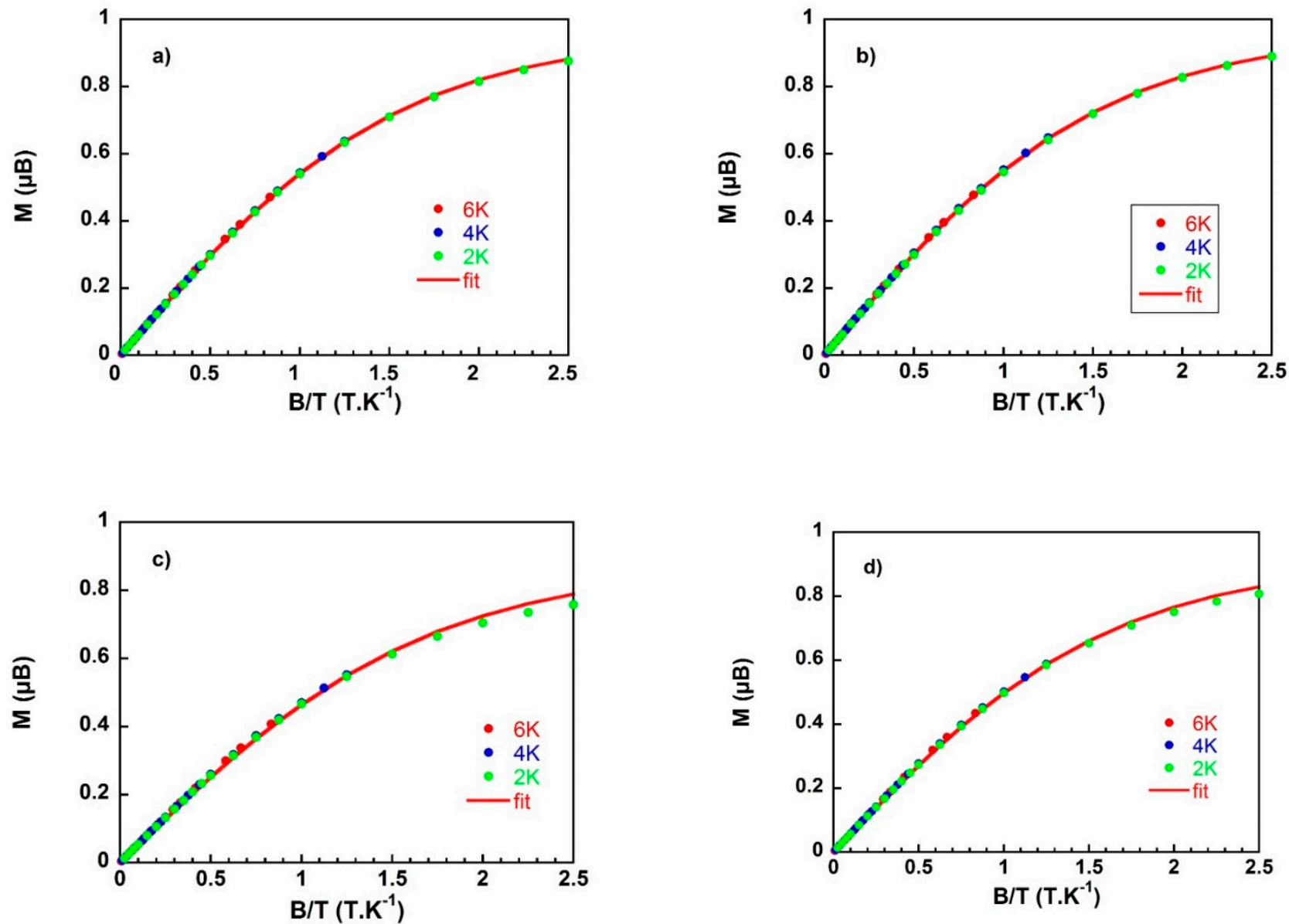

Figure 12. $M$ vs. $B / T$ measurements for $\alpha_{1}$-As (a), $\alpha_{2}$-As (b), $\alpha_{1}-\mathrm{P}(\mathbf{c}), \alpha_{2}-\mathrm{P}(\mathbf{d})$ : experimental data at $6 \mathrm{~K}(\bullet), 4 \mathrm{~K}(\bullet)$, and $2 \mathrm{~K}(\bullet)$; Brillouin function (-) for a $\mathrm{S}=1 / 2$ ion. The $\mathrm{g}$ values are given in Table 3.

For the $\mathrm{AsV}^{4+}$ compound, the $g$ values obtained, even if weak, were in agreement with the values found in the literature [56,57], but those obtained for the $\mathrm{PV}^{4+}$ compound were very weak, confirming the possible underestimation of the molar mass for these compounds (Table 3 ).

Despite the experimental difficulties related to the weak magnetization of these POMs (a spin of $1 / 2$ in a large diamagnetic matrix), it was confirmed that the $\mathrm{V}^{4+}$-containing compounds behaved as isolated $\mathrm{S}=1 / 2$ monomers, while the $\mathrm{V}^{5+}$-containing ones were globally diamagnetic.

\section{Conclusions}

The redox behaviour of four POMs from the Dawson family was studied in detail using cyclic voltammetry. New observations were made regarding the influence of the $\mathrm{pH}$ of the electrolyte on the nature of electron transfer and the evolution of the associated redox potentials. The position of the V substituent within the POM structure, $\alpha_{1}$ or $\alpha_{2}$, had a very marked influence on the behaviour of the redox waves associated with the tungstic skeleton. The low-temperature magnetic behaviour of these four compounds containing a $\mathrm{V}^{\mathrm{IV}}$ centre was compared to that of their counterparts containing a $\mathrm{V}^{\mathrm{V}}$ centre, which confirmed a paramagnetic behaviour for the former and a diamagnetic behaviour for the latter. 
Supplementary Materials: The following are available online at https: / www.mdpi.com/article/ $10.3390 /$ magnetochemistry7120157/s1. S1. Cyclic voltammetry characterisation at pH $3.0(0.2 \mathrm{M}$ $\left.\mathrm{Na}_{2} \mathrm{SO}_{4}+\mathrm{H}_{2} \mathrm{SO}_{4}\right)$. Working electrode: GC; counter electrode: Pt; reference electrode: SCE. Scan rate: $10 \mathrm{mV} \mathrm{s}^{-1}$. Figure S1. CVs of (a) $\alpha_{2}$-As (black) and $\alpha_{2}-\mathrm{P}$ (red); (b) $\alpha_{1}-\mathrm{P}$ (black) and $\alpha_{2}-\mathrm{P}$ (red). Figure S2. CVs of (a) $\alpha_{1}$-As (black) and $\alpha_{2}$-As (red); (b) $\alpha_{1}-\mathrm{P}$ (black) and $\alpha_{2}-\mathrm{P}$ (red). S2. Cyclic voltammetry characterisation in three different media: $0.2 \mathrm{M} \mathrm{Na}_{2} \mathrm{SO}_{4}+\mathrm{H}_{2} \mathrm{SO}_{4} / \mathrm{pH} 3.0$ (black), $0.4 \mathrm{M}$ $\mathrm{CH}_{3} \mathrm{CO}_{2} \mathrm{Na}+\mathrm{CH}_{3} \mathrm{CO}_{2} \mathrm{H} / \mathrm{pH} 5.0$ (red) and $0.2 \mathrm{M} \mathrm{Na}_{2} \mathrm{HPO}_{4}+\mathrm{H}_{3} \mathrm{PO}_{4} / \mathrm{pH}$ 7.0. Figure S3. CVs of (a) $\alpha_{1}$-As; (b) $\alpha_{1}$-P; (c) $\alpha_{2}$-As and (d) $\alpha_{2}$-P. Table S1. Oxidation peak potentials $\left(E_{a}\right)$ and reduction peak potentials $\left(E_{c}\right)$ measured from $\mathrm{CVs}$ recorded in $0.4 \mathrm{M} \mathrm{CH}_{3} \mathrm{CO}_{2} \mathrm{Na}+\mathrm{CH}_{3} \mathrm{CO}_{2} \mathrm{H} / \mathrm{pH}$ 5.0. Table S2. Oxidation peak potentials $\left(E_{a}\right)$ and reduction peak potentials $\left(E_{c}\right)$ measured from $C V$ s recorded in $0.2 \mathrm{M} \mathrm{Na}_{2} \mathrm{HPO}_{4}+\mathrm{H}_{3} \mathrm{PO}_{4} / \mathrm{pH}$ 7.0. Table S3. Preparation of the Britton-Robinson buffer solution. Figure S4. CVs of $\alpha_{1}-\mathrm{P}$ (black) and $\alpha_{2}-\mathrm{P}$ (red) in Britton-Robinson buffer. (a) pH 1.0; (b) pH 2.3; (c) $\mathrm{pH} 3.8$; (d) $\mathrm{pH} 4.7$; (e) $\mathrm{pH}$ 6.3. Figure S5. CVs of $\alpha_{2}-\mathrm{P}$ in Britton-Robinson buffer at (a) $\mathrm{pH} 1.0$ (black) and pH 2.5 (red); (b) pH 3.5 (black) and pH 5.0 (red). S4. Electro-catalytic properties. Figure S6 (a) CVs of $\alpha_{2}-\mathrm{P}$ alone (black) and in the presence of thiol (red); (b) CVs of $\alpha_{1}-\mathrm{P}$ (black) and $\alpha_{2}-\mathrm{P}$ (red), both alone. Figure S7. CVs of $\alpha_{1}$-As (black) and $\alpha_{2}$-As (red): (a) alone and (b) in presence of thiol. S5. Magnetic properties. Figure S8: Theoretical susceptibility under an applied field of $1 \mathrm{~T}$ in the form of a $\chi_{\mathrm{m}} \mathrm{T}$ vs. T plot for a $\mathrm{S}=1 / 2$ ion. S.6. Syntheses of different POMs.

Author Contributions: Conceptualization, I.M.M.; methodology, I.M.M.; validation, I.M.M., E.R. and P.d.O.; formal analysis, J.D.M., E.R., P.d.O. and I.M.M.; investigation, J.D.M., E.R., P.d.O. and I.M.M.; resources, A.-L.T.; writing-original draft preparation, E.R. and I.M.M.; writing-review and editing, I.M.M., E.R. and P.d.O.; supervision, I.M.M. All authors have read and agreed to the published version of the manuscript.

Funding: This research received no external funding.

Institutional Review Board Statement: Not applicable.

Informed Consent Statement: Not applicable.

Conflicts of Interest: The authors declare no conflict of interest.

\section{References}

1. Pope, M.T.; Müller, A. Polyoxometalate Chemistry: An Old Field with New Dimensions in Several Disciplines. Angew. Chem. Int. Ed. Engl. 1991, 30, 34-48. [CrossRef]

2. Pope, M. Heteropoly and Isopoly Oxometalates, 1st ed.; Springer: Berlin/Heidelberg, Germany, 1983.

3. Contant, R.; Thouvenot, R. Hétéropolyanions de type Dawson. 2. Synthèses de polyoxotungstoarsénates lacunaires dérivant de l'octadécatungstodiarsénate. Étude structurale par RMN du tungstène-183 des octadéca(molybdotungstovanado)diarsénates apparentés. Can. J. Chem. 1991, 69, 1498-1506. [CrossRef]

4. Dawson, B. The structure of the 9(18)-heteropoly anion in potassium 9(18)-tungstophosphate, $\mathrm{K}_{6}\left(\mathrm{P}_{2} \mathrm{~W}_{18} \mathrm{O}_{62}\right) \cdot 14 \mathrm{H}_{2} \mathrm{O}$. Acta Crystallogr. 1953, 6, 113-126. [CrossRef]

5. Lefort, J. Action des acides arsénique et phosphorique sur les tungstates de soude et nouvelle méthode d'analyse des tungstates. Ann. Chim. Phys. 1882, XXV, 200-210.

6. Souchay, P. Tungstic heteropolyacids. VIII. Phosphotungstates. Ann. Chim 1947, 2, 203-222.

7. Contant, R.; Thouvenot, R. A reinvestigation of isomerism in the Dawson structure: Syntheses and 183W NMR structural characterization of three new polyoxotungstates $\left[\mathrm{X}_{2} \mathrm{~W}_{18} \mathrm{O}_{62}\right]^{6-}(\mathrm{X}=\mathrm{PV}, \mathrm{AsV})$. Inorg. Chim. Acta 1993, 212, 41-50. [CrossRef]

8. Belghiche, R.; Contant, R.; Lu, Y.W.; Keita, B.; Abbessi, M.; Nadjo, L.; Mahuteau, J. Synthesis and characterization of Fe- or Cu-substituted molybdenum-enriched tungstodiphosphates. Eur. J. Inorg. Chem. 2002, 6, 1410-1414. [CrossRef]

9. Contant, R.; Richet, M.; Lu, Y.W.; Keita, B.; Nadjo, L. Isomerically pure $\alpha_{1}$-monosubstituted tungstodiphosphates: Synthesis, characterization and stability in aqueous solutions. Eur. J. Inorg. Chem. 2002, 10, 2587-2593. [CrossRef]

10. Nishiki, K.; Umehara, N.; Kadota, Y.; Lopez, X.; Poblet, J.M.; Mezui, C.A.; Teillout, A.-L.; Mbomekalle, I.M.; de Oliveira, P.; Miyamoto, M.; et al. Preparation of $\alpha_{1}$ - and $\alpha_{2}$-isomers of mono-Ru-substituted Dawson-type phosphotungstates with an aqua ligand and comparison of their redox potentials, catalytic activities, and thermal stabilities with Keggin-type derivatives. Dalton Trans. 2016, 45, 3715-3726. [CrossRef]

11. Keita, B.; Lu, Y.W.; Nadjo, L.; Contant, R.; Abbessi, M.; Canny, J.; Richet, M. Electrochemical and catalytic behavior of Dawsontype complexes derived from $\left[(1), 2,3-\mathrm{P}_{2} \mathrm{Mo}_{2} \mathrm{~W}_{15} \mathrm{O}_{61}\right]^{10-}$ and first transition metal ions. J. Electroanal. Chem. 1999, 477, 146-157. [CrossRef]

12. Contant, R.; Abbessi, M.; Canny, J.; Richet, M.; Keita, B.; Belhouari, A.; Nadjo, L. Synthesis, characterization and electrochemistry of complexes derived from $\left[(1), 2,3-\mathrm{P}_{2} \mathrm{Mo}_{2} \mathrm{~W}_{15} \mathrm{O}_{61}\right]^{10-}$ and first-row transition metal ions. Eur. J. Inorg. Chem. 2000, 3, 567-574. [CrossRef] 
13. Abbessi, M.; Contant, R.; Thouvenot, R.; Herve, G. Dawson type heteropolyanions. 1. Multinuclear (phosphorus-31, vanadium-51, tungsten-183) NMR structural investigations of octadeca(molybdotungstovanado)diphosphates .alpha.- $-1,2,3-\left[\mathrm{P}_{2} \mathrm{MM}_{2} \mathrm{~W}_{15} \mathrm{O}_{62}\right] \mathrm{n}-$ $\left(\mathrm{M}, \mathrm{M}^{\prime}=\mathrm{Mo}, \mathrm{V}, \mathrm{W}\right)$ : Syntheses of new related compounds. Inorg. Chem. 1991, 30, 1695-1702. [CrossRef]

14. Contant, R.; Abbessi, M.; Thouvenot, R.; Hervé, G. Dawson Type Heteropolyanions. 3. Syntheses and 31P, 51V, and 183W NMR Structural Investigation of Octadeca(molybdo-tungsto-vanado)diphosphates Related to the $\left[\mathrm{H}_{2} \mathrm{P}_{2} \mathrm{~W}_{12} \mathrm{O}_{48}\right] 12-\mathrm{Anion}$. Inorg. Chem. 2004, 43, 3597-3604. [CrossRef]

15. Finke, R.G.; Rapko, B.; Saxton, R.J.; Domaille, P.J. Trisubstituted heteropolytungstates as soluble metal oxide analogs. III. Synthesis, characterization, phosphorus-31, silicon-29, vanadium-51, and 1- and 2-D tungsten-183 NMR, deprotonation, and proton mobility studies of organic solvent solute forms of $\mathrm{HxSiW}_{9} \mathrm{~V}_{3} \mathrm{O}_{40} \mathrm{x}_{-7}$ and $\mathrm{HxP}_{2} \mathrm{~W}_{15} \mathrm{~V}_{3} \mathrm{O}_{62} \mathrm{X}_{-9}$. J. Am. Chem. Soc. 1986, 108, $2947-2960$.

16. Harmalker, S.P.; Leparulo, M.A.; Pope, M.T. Mixed-valence chemistry of adjacent vanadium centers in heteropolytungstate anions. I. Synthesis and electronic structures of mono-, di-, and trisubstituted derivatives of alpha.-octadecatungstodiphosphate(6-) ion (.alpha.-[ $\left.\left.\mathrm{P}_{2} \mathrm{~W}_{18} \mathrm{O}_{62}\right] 6-\right)$. J. Am. Chem. Soc. 1983, 105, 4286-4292. [CrossRef]

17. Keita, B.; Girard, F.; Nadjo, L.; Contant, R.; Canny, J.; Richet, M. Metal ion complexes derived from the $\alpha_{1}$ isomer of $\left(\mathrm{P}_{2} \mathrm{~W}_{17} \mathrm{O}_{61}\right) 10-$ : Comparison with the corresponding $\alpha_{2}$ species. J. Electroanal. Chem. 1999, 478, 76-82. [CrossRef]

18. Tommasino, J.B.; Contant, R.; Michaut, J.P.; Roncin, J. Electrochemical characterization of a series of substituted Dawson type tungstophosphates $\alpha[$ P2W18-xMozVyO62]n- $(x=y+z ; n=6+y)$. Polyhedron 1997, 17, 357-366. [CrossRef]

19. Finke, R.G.; Droege, M.W. Trivacant heteropolytungstate derivatives. 2. Synthesis, characterization, and tungsten-183 NMR of $\mathrm{P}_{4} \mathrm{~W}_{30} \mathrm{M}_{4}\left(\mathrm{H}_{2} \mathrm{O}\right)_{2} \mathrm{O}_{11216}{ }^{-}(\mathrm{M}=\mathrm{Co}, \mathrm{Cu}, \mathrm{Zn})$. Inorg. Chem. 1983, 22, 1006-1008. [CrossRef]

20. Weakley, T.J.R.; Finke, R.G. Single-crystal X-ray structures of the polyoxotungstate salts $\mathrm{K}_{8.3} \mathrm{Na}_{1.7}\left[\mathrm{Cu}_{4}\left(\mathrm{H}_{2} \mathrm{O}\right)_{2}\left(\mathrm{PW}_{9} \mathrm{O}_{34}\right)_{2}\right] . c n t d o t .24 \mathrm{H}_{2} \mathrm{O}$ and $\mathrm{Na}_{14} \mathrm{Cu}\left[\mathrm{Cu}_{4}\left(\mathrm{H}_{2} \mathrm{O}\right)_{2}\left(\mathrm{P}_{2} \mathrm{~W}_{15} \mathrm{O}_{56}\right)_{2}\right]$. cntdot.53H $\mathrm{H}_{2} \mathrm{O}$. Inorg. Chem. 1990, 29, 1235-1241. [CrossRef]

21. Gomez-Garcia, C.J.; Borras-Almenar, J.J.; Coronado, E.; Ouahab, L. Single-Crystal X-ray Structure and Magnetic Properties of the Polyoxotungstate Complexes $\mathrm{Na}_{16}\left[\mathrm{M}_{4}\left(\mathrm{H}_{2} \mathrm{O}\right)_{2}\left(\mathrm{P}_{2} \mathrm{~W}_{15} \mathrm{O}_{56}\right)_{2}\right]$.cntdot. $\mathrm{nH}_{2} \mathrm{O}(\mathrm{M}=\mathrm{MnII}, \mathrm{n}=53 ; \mathrm{M}=\mathrm{NiII}, \mathrm{n}=52)$ : An Antiferromagnetic MnII Tetramer and a Ferromagnetic NiII Tetramer. Inorg. Chem. 1994, 33, 4016-4022. [CrossRef]

22. Zhang, X.; Chen, Q.; Duncan, D.C.; Campana, C.F.; Hill, C.L. Multiiron Polyoxoanions. Syntheses, Characterization, X-ray Crystal Structures, and Catalysis of $\mathrm{H}_{2} \mathrm{O}_{2}$-Based Hydrocarbon Oxidations by $\left[\mathrm{FeIII}_{4}\left(\mathrm{H}_{2} \mathrm{O}\right)_{2}\left(\mathrm{P}_{2} \mathrm{~W}_{15} \mathrm{O}_{56}\right)_{2}\right]_{12}$. Inorg. Chem. 1997, 36, 4208-4215. [CrossRef]

23. Bi, L.-H.; Wang, E.-B.; Peng, J.; Huang, R.-D.; Xu, L.; Hu, C.-W. Crystal Structure and Replacement Reaction of Coordinated Water Molecules of the Heteropoly Compounds of Sandwich-Type Tungstoarsenates. Inorg. Chem. 2000, 39, 671-679. [CrossRef]

24. Ruhlmann, L.; Canny, J.; Contant, R.; Thouvenot, R. Di- and Tricobalt Dawson Sandwich Complexes: Synthesis, Spectroscopic Characterization, and Electrochemical Behavior of $\mathrm{Na}_{18}\left[\left(\mathrm{NaOH}_{2}\right)_{2} \mathrm{Co}_{2}\left(\mathrm{P}_{2} \mathrm{~W}_{15} \mathrm{O}_{56}\right)_{2}\right]$ and $\mathrm{Na}_{17}\left[\left(\mathrm{NaOH}_{2}\right) \mathrm{Co}_{3}\left(\mathrm{H}_{2} \mathrm{O}\right)\left(\mathrm{P}_{2} \mathrm{~W}_{15} \mathrm{O}_{56}\right)_{2}\right]$. Inorg. Chem. 2002, 41, 3811-3819. [CrossRef]

25. Clemente-Juan, J.M.; Coronado, E.; Gaita-Ariño, A.; Giménez-Saiz, C.; Güdel, H.-U.; Sieber, A.; Bircher, R.; Mutka, H. Magnetic Polyoxometalates: Anisotropic Exchange Interactions in the Moiety of $\left[\left(\mathrm{NaOH}_{2}\right) \mathrm{Co}_{3}\left(\mathrm{H}_{2} \mathrm{O}\right)\left(\mathrm{P}_{2} \mathrm{~W}_{15} \mathrm{O}_{56}\right)_{2}\right]_{17}$. Inorg. Chem. 2005, 44, 3389-3395. [CrossRef] [PubMed]

26. Anderson, T.M.; Fang, X.; Mbomekalle, I.M.; Keita, B.; Nadjo, L.; Hardcastle, K.I.; Farsidjani, A.; Hill, C.L. Structural and Electrochemical Studies of Dicupric Wells-Dawson Sandwich-Type Complexes. J. Clust. Sci. 2006, 17, 183-195. [CrossRef]

27. Ruhlmann, L.; Costa-Coquelard, C.; Canny, J.; Thouvenot, R. Mixed-Metal Dawson Sandwich Complexes: Synthesis, Spectroscopic Characterization and Electrochemical Behaviour of $\mathrm{Na}_{16}\left[\mathrm{MIICo}_{3}\left(\mathrm{H}_{2} \mathrm{O}\right)_{2}\left(\mathrm{P}_{2} \mathrm{~W}_{15} \mathrm{O}_{56}\right)_{2}\right](\mathrm{M}=\mathrm{Mn}, \mathrm{Co}, \mathrm{Ni}, \mathrm{Zn}$ and Cd). Eur. J. Inorg. Chem. 2007, 2007, 1493-1500. [CrossRef]

28. Mbomekalle, I.M.; Keita, B.; Nadjo, L.; Berthet, P.; Hardcastle, K.I.; Hill, C.L.; Anderson, T.M. Multi-Iron Tungstodiarsenates. Synthesis, Characterization, and Electrocatalytic Studies of $\alpha \beta \beta \alpha-\left(\mathrm{FeIIIOH}_{2}\right)_{2} \mathrm{FeIII}_{2}\left(\mathrm{As}_{2} \mathrm{~W}_{15} \mathrm{O}_{56}\right)_{212}$. Inorg. Chem. 2003, 42, 1163-1169. [CrossRef]

29. Mbomekalle, I.M.; Keita, B.; Nadjo, L.; Berthet, P.; Neiwert, W.A.; Hill, C.L.; Ritorto, M.D.; Anderson, T.M. Manganous heteropolytungstates. Synthesis and heteroatom effects in Wells-Dawson-derived sandwich complexes. Dalton Trans. 2003, 13, 2646-2650. [CrossRef]

30. Mbomekalle, I.M.; Mialane, P.; Dolbecq, A.; Marrot, J.; Secheresse, F.; Berthet, P.; Keita, B.; Nadjo, L. Rational Synthesis, Structure, Magnetism and Electrochemistry of Mixed Iron-Nickel-Containing Wells-Dawson-Fragment-Based Sandwich-Type Polyoxometalates. Eur. J. Inorg. Chem. 2009, 34, 5194-5204. [CrossRef]

31. Bassil, B.S.; Xiang, Y.; Haider, A.; Hurtado, J.; Novitchi, G.; Powell, A.K.; Bossoh, A.M.; Mbomekalle, I.M.; de Oliveira, P.; Kortz, U. Heptanickel(II) double-cubane core in Wells-Dawson heteropolytungstate, $\left[\mathrm{Ni}_{7}(\mathrm{OH})_{6}\left(\mathrm{H}_{2} \mathrm{O}\right)_{6}\left(\mathrm{P}_{2} \mathrm{~W}_{15} \mathrm{O}_{56}\right)_{2}\right]_{16}$. Chem. Commun. 2016, 52, 2601-2604. [CrossRef]

32. Bassil, B.S.; Bossoh, A.M.; Ibrahim, M.; Bile, B.A.; Mougharbel, A.S.; Lin, Z.; de Oliveira, P.; Mbomekalle, I.-M.; Kortz, U. Synthesis, Structure and Electrochemistry of the Dinickel(II)-Containing 30-Tungsto-4-Phosphate [Ni2Na2(H2O)2(P2W15O56)2]18. Curr. Inorg. Chem. 2017, 7, 21-27. [CrossRef]

33. Mbomekalle, I.M.; Cao, R.; Hardcastle, K.I.; Hill, C.L.; Ammam, M.; Keita, B.; Nadjo, L.; Anderson, T.M. Synthesis, structural characterization, and electrocatalytic studies of $\alpha \beta \beta \alpha-\left(\mathrm{ZnIIOH}_{2}\right)_{2}(\mathrm{FeIII})_{2}\left(\mathrm{X}_{2} \mathrm{~W}_{15} \mathrm{O}_{56}\right)_{2}{ }^{14-}(\mathrm{X}=\mathrm{P}$ or As). C. R. Chim. 2005, 8, 1077-1086. [CrossRef] 
34. Ayingone Mezui, C.S.; de Oliveira, P.; Teillout, A.-L.; Marrot, J.; Berthet, P.; Lebrini, M.; Mbomekallé, I.M. Synthesis, Structure, and Magnetic Electrochemical Properties of a Family of Tungstoarsenates Containing Just CoII Centers or Both CoII and FeIII Centers. Inorg. Chem. 2017, 56, 1999-2012. [CrossRef]

35. Floriant, D.; Charyle, S.A.M.; de Pedro, O.; Anne-Lucie, T.; Israel, M.M. Synthesis, Electrochemistry and Electro-Catalytic Properties of The Mixed Copper-Iron-Containing Sandwich-Type Polyoxometalates $\left[(\mathrm{FeIIIOH})_{2} \mathrm{CuII} 2\left(\mathrm{X}_{2} \mathrm{~W}_{15} \mathrm{O}_{56}\right)_{2}\right]^{14-}$ and $\left[\left(\mathrm{CuIIOH}_{2}\right)_{2} \mathrm{FeIII}_{2}\left(\mathrm{X}_{2} \mathrm{~W}_{15} \mathrm{O}_{56}\right)_{2}\right]^{14-}$ (with $\mathrm{X}=\mathrm{AsV}$ and PV). Curr. Inorg. Chem. (Discontin.) 2017, 7, $28-38$.

36. Mbomekalle, I.-M.; Bassil, B.S.; Suchopar, A.; Keita, B.; Nadjo, L.; Ammam, M.; Haouas, M.; Taulelle, F.; Kortz, U. Improved Synthesis, Structure, and Solution Characterization of the Cyclic 48-Tungsto-8-Arsenate $\left.(\mathrm{V}), \mathrm{H}_{4} \mathrm{As}_{8} \mathrm{~W}_{48} \mathrm{O}_{184}\right]^{36-}$. J. Cluster Sci. 2014, 25, 277-285. [CrossRef]

37. Liu, G.; Liu, T.; Mal, S.S.; Kortz, U. Wheel-Shaped Polyoxotungstate [Cu20Cl(OH)24(H2O)12(P8W48O184)]25- Macroanions Form Supramolecular "Blackberry" Structure in Aqueous Solution. J. Am. Chem. Soc. 2006, 128, 10103-10110. [CrossRef]

38. Ismail, A.H.; Bassil, B.S.; Yassin, G.H.; Keita, B.; Kortz, U. \{W48\} ring opening: Fe16-containing, Ln4-stabilized 49-tungsto-8phosphateopen wheel $\left[\mathrm{Fe}_{16} \mathrm{O}_{2}(\mathrm{OH})_{23}\left(\mathrm{H}_{2} \mathrm{O}\right)_{9}\left(\mathrm{P}_{8} \mathrm{~W}_{49} \mathrm{O}_{189}\right) \mathrm{Ln}_{4}\left(\mathrm{H}_{2} \mathrm{O}\right)_{20}\right]^{11-}$. Chemistry 2012, 18, 6163-6166. [CrossRef]

39. Mal, S.S.; Kortz, U. The Wheel-Shaped $\mathrm{Cu}_{20}$ Tungstophosphate $\left[\mathrm{Cu}_{20} \mathrm{Cl}(\mathrm{OH})_{24}\left(\mathrm{H}_{2} \mathrm{O}\right)_{12}\left(\mathrm{P}_{8} \mathrm{~W}_{48} \mathrm{O}_{184}\right)\right]^{25-}$ Ion. Angew. Chem. Int. Ed. 2005, 44, 3777-3780. [CrossRef]

40. Contant, R.; Teze, A. A new crown heteropolyanion $\mathrm{K}_{28} \mathrm{Li}_{5} \mathrm{H}_{7} \mathrm{P}_{8} \mathrm{~W}_{48} \mathrm{O}_{184} \cdot 92 \mathrm{H}_{2} \mathrm{O}$ : Synthesis, structure, and properties. Inorg. Chem. 1985, 24, 4610-4614. [CrossRef]

41. Keita, B.; Mbomekalle, I.-M.; Nadjo, L.; de Oliveira, P.; Ranjbari, A.; Contant, R. Vanadium-substituted Dawson-type polyoxometalates as versatile electrocatalysts. C. R. Chim. 2005, 8, 1057-1066. [CrossRef]

42. Mbomekalle, I.M.; Keita, B.; Nadjo, L.; Contant, R.; Belai, N.; Pope, M.T. Rationalization and improvement of the syntheses of two octadecatungstoarsenates: The novel $\alpha-\mathrm{K}_{7}\left[\mathrm{H}_{4} \mathrm{AsW} \mathrm{H}_{18} \mathrm{O}_{62}\right] \cdot 18 \mathrm{H}_{2} \mathrm{O}$ and the well known symmetrical $\alpha-\mathrm{K}_{6}\left[\mathrm{As}_{2} \mathrm{~W}_{18} \mathrm{O}_{62}\right] \cdot 14 \mathrm{H} 2 \mathrm{O}$. Inorg. Chim. Acta 2003, 342, 219-228. [CrossRef]

43. Mbomekalle, I.-M.; Lu, Y.W.; Keita, B.; Nadjo, L. Simple, high yield and reagent-saving synthesis of pure $\alpha-\mathrm{K}_{6} \mathrm{P}_{2} \mathrm{~W}_{18} \mathrm{O}_{62} 14 \mathrm{H}_{2} \mathrm{O}$. Inorg. Chem. Commun. 2003, 7, 86-90. [CrossRef]

44. Sadakane, M.; Steckhan, E. Electrochemical Properties of Polyoxometalates as Electrocatalysts. Chem. Rev. 1998, 98, 219-238. [CrossRef]

45. Ueda, T. Electrochemistry of Polyoxometalates: From Fundamental Aspects to Applications. ChemElectroChem 2018, 5, 823-838. [CrossRef]

46. Keita, B.; Nadjo, L. Electrochemistry of Isopoly and Heteropoly Oxometalates. In Encyclopedia of Electrochemistry; Bard, A.J., Stratmann, M., Eds.; Wiley-VCH: Weinheim, Germany, 2005; Volume 7.

47. Vila, N.; Aparicio, P.A.; Secheresse, F.; Poblet, J.M.; Lopez, X.; Mbomekalle, I.M. Electrochemical behavior of alpha1/alpha2[Fe(H2O)P2W17O61](7-) isomers in solution: Experimental and DFT studies. Inorg. Chem. 2012, 51, 6129-6138. [CrossRef]

48. Keita, B.; Mbomekalle, I.M.; Nadjo, L.; Contant, R. Compared behaviours of Dawson-type tungstodiarsenates and -diphosphates. Eur. J. Inorg. Chem. 2002, 2, 473-479. [CrossRef]

49. Keita, B.; Mbomekalle, I.M.; de Oliveira, P.; Ranjbari, A.; Justum, Y.; Nadjo, L.; Pompon, D. Reactions of V-substituted polyoxometalates with L-cysteine. J. Cluster Sci. 2006, 17, 221-233. [CrossRef]

50. Mbomekallé, I.-M.; López, X.; Poblet, J.M.; Sécheresse, F.; Keita, B.; Nadjo, L. Influence of the Heteroatom Size on the Redox Potentials of Selected Polyoxoanions. Inorg. Chem. 2010, 49, 7001-7006. [CrossRef] [PubMed]

51. Pope, M.T.; Varga, G.M. Heteropoly Blues. I. Reduction Stoichiometries and Reduction Potentials of Some 12-Tungstates. Inorg. Chem. 1966, 5, 1249-1254. [CrossRef]

52. Nakajima, K.; Eda, K.; Himeno, S. Effect of the Central Oxoanion Size on the Voltammetric Properties of Keggin-Type $\left[\mathrm{XW}_{12} \mathrm{O}_{40}\right]^{\mathrm{n}-}$ ( $\mathrm{n}=2-6)$ Complexes. Inorg. Chem. 2010, 49, 5212-5215. [CrossRef]

53. Keita, B.; Lu, Y.W.; Nadjo, L.; Contant, R. Influence of charge distribution on the properties of Keggin- and Dawson-type heteropolyanions. Eur. J. Inorg. Chem. 2000, 12, 2463-2471. [CrossRef]

54. Keita, B.; Jean, Y.; Levy, B.; Nadjo, L.; Contant, R. Toward a qualitative understanding of the initial electron transfer site in Dawson-type heteropolyanions. New J. Chem. 2002, 26, 1314-1319. [CrossRef]

55. Kahn, O. Molecular Magnetism; VCH: New York, NY, USA, 1993.

56. Mialane, P.; Marrot, J.; Rivière, E.; Nebout, J.; Hervé, G. Structural Characterization and Magnetic Properties of Sandwich-Type Tungstoarsenate Complexes. Study of a Mixed-Valent VIV2/VV Heteropolyanion. Inorg. Chem. 2001, 40, 44-48. [CrossRef] [PubMed]

57. Miras, H.N.; Raptis, R.G.; Lalioti, N.; Sigalas, M.P.; Baran, P.; Kabanos, T.A. A novel series of vanadium-sulfite polyoxometalates: Synthesis, structural, and physical studies. Chemistry 2005, 11, 2295-2306. [CrossRef] [PubMed] 